Article

\title{
Synergistic Degradation of Dye Wastewaters Using Binary or Ternary Oxide Systems with Immobilized Laccase
}

\author{
Katarzyna Antecka ${ }^{1}$, Jakub Zdarta ${ }^{1}$, Katarzyna Siwińska-Stefańska ${ }^{1}$, Grzegorz Sztuk ${ }^{1}$, \\ Ewelina Jankowska ${ }^{2}$, Piotr Oleskowicz-Popiel ${ }^{2}$ and Teofil Jesionowski ${ }^{1, *}$ \\ 1 Institute of Chemical Technology and Engineering, Faculty of Chemical Technology, Poznan University of \\ Technology, Berdychowo 4, 60965 Poznan, Poland; katarzyna.a.antecka@doctorate.put.poznan.pl (K.A.); \\ jakub.zdarta@put.poznan.pl (J.Z.); katarzyna.siwinska-stefanska@put.poznan.pl (K.S.-S.); \\ grzegorz.sztuk@student.put.poznan.pl (G.S.) \\ 2 Institute of Environmental Engineering, Faculty of Civil and Environmental Engineering, Poznan University \\ of Technology, Berdychowo 4, 60965 Poznan, Poland; ewelina.jankowska@put.poznan.pl (E.J.); \\ piotr.oleskowicz-popiel@put.poznan.pl (P.O.-P.) \\ * Correspondence: Teofil.Jesionowski@put.poznan.pl; Tel.: +48-616-65-3720
}

Received: 13 August 2018; Accepted: 15 September 2018; Published: 18 September 2018

\begin{abstract}
In recent years, groundwater contamination caused by dyes has become an important problem. They enter into wastewater as a result of the textile, automotive, or cosmetics industries. For this reason, new methods are being sought, which would aid at the removal of dye impurities with high efficiency and also would be relatively cheap. In the presented study synthesized $\mathrm{TiO}_{2}-\mathrm{ZrO}_{2}$ (with $\mathrm{TiO}_{2}: \mathrm{ZrO}_{2}$ molar ratio of 8:2) and $\mathrm{TiO}_{2}-\mathrm{ZrO}_{2}-\mathrm{SiO}_{2}$ (with $\mathrm{TiO}_{2}: \mathrm{ZrO}_{2}: \mathrm{SiO}_{2}$ molar ratio of 8:1:1) oxide materials were used as supports for enzyme immobilization. Effective synthesis of the carriers was confirmed by results of scanning electron microscopy (SEM), transmission electron microscopy (TEM), X-ray diffraction (XRD), low-temperature nitrogen sorption and Fourier transform infrared spectroscopy (FTIR). The materials achieve high immobilization efficiency of the laccases from Trametes versicolor $\left(83 \%\right.$ and $96 \%$ for $\mathrm{TiO}_{2}-\mathrm{ZrO}_{2}-\mathrm{laccase}$ and $\mathrm{TiO}_{2}-\mathrm{ZrO}_{2}-\mathrm{SiO}_{2}-\mathrm{laccase}_{\text {, }}$ respectively). The effect of selected dye concentrations, $\mathrm{pH}$, temperature, and reusability were also tested. The obtained results showed that after removal of textile dyes, such as Alizarin Red S (ARS), Remazol Brilliant Blue R (RBBR), and Reactive Black 5 (RB5), under optimal process conditions, which were $\mathrm{pH} 5$ and $25^{\circ} \mathrm{C}$, from dye solution of $5 \mathrm{mg} / \mathrm{L}$ degradation efficiency reached $100 \%, 91 \%$, and $77 \%$, respectively, suggesting synergistic mechanism of degradation by simultaneous sorption and catalytic action. Finally, reduction of chemical oxygen demand (COD) of the solution after treatment indicated lower mixture toxicity and effective dye degradation.
\end{abstract}

Keywords: oxide materials; hybrid supports; dyes; enzyme immobilization; laccase; environmental protection

\section{Introduction}

In recent years, the removal of hazardous pollutants originating from many industries has become an important issue for environmental protection. Cosmetics, pharmaceutical, textile, paper, plastic, or car industries generate huge amounts of pollution, which then can get through into groundwater and even drinking water [1,2]. One of the most harmful impurities are dyes, which are designed to give color to specific products. They can be divided into groups, such as: acid dyes, basic dyes, direct dyes, disperse dyes, reactive dyes, and vat dyes. For example, basic, direct and disperse dyes are used for coloring paper as vat dyes for flax wool cotton [3]. It should be emphasized that even 
up to $40 \%$ of dyes used in industry goes to sewage and most of the dyes presenting in wastewaters come from the textile industry $[4,5]$. The toxicity of dyes is related to their complicated structures with many functional groups such as $-\mathrm{NR}_{2},-\mathrm{NHR},-\mathrm{NH}_{2},-\mathrm{COOH},-\mathrm{OH},-\mathrm{NO},-\mathrm{NO}_{2}$ and, most of all, the presence of phenolic rings [3,6]. These compounds cause coloration of water, which inhibits sunlight transmission, leading to dying of the ecosystem. After entering the human body, they can cause serious illnesses such as allergies, gene mutations, heart disease or cancers [7,8]. For this reason, even a small amount of dyes in groundwater and drinking water is undesirable.

To improve the quality of life in the 21st century, new methods are being sought to remove pollutants; i.e., dyes from wastewater. Many methods are used, such as adsorption, coagulation, photocatalysis, although not all of the above-mentioned are efficient enough [9]. It is related to the type of removed dye and conditions of the removal process. Moreover, they are not applicable on an industrial scale as they generate high costs. For example, the adsorption method is effective depending on the adsorbent and adsorbate; ion exchange is not effective for disperse dyes, during membrane filtration the production of huge amounts of sludge occurs and there is need to use sophisticated equipment and high costs as a result of electricity consumption [10-15]. Thus, more and more interest is aroused by enzymes as a way of removing dyes from water. One of such biomolecules is laccase (EC 1.10.3.2), which catalyzes the oxidation reactions of derivatives of phenolic or non-phenolic compounds, mainly mono-, di- and polyphenols with a simultaneous reduction of molecular oxygen to water [16]. The low stability of free enzymes limits their practical use, which is a reason to use immobilization, which improves practical properties and application of the biocatalysts [17]. For this reason, laccases can be also used to remove dyes from aqueous solutions. For example, Faraco et al. used laccase from Phanerochaete chrysosporium and Pleurotus ostreatus, immobilized on Cu-alginate beads to remove acid (Acid Blue 62, Acid Yellow 49, Acid Red 266), reactive (Reactive Blue 222, Reactive Red 195, Reactive Yellow 145, Reactive Black 5) and direct dyes (Direct Blue 71, Direct Red 80, Direct Yellow 106) with the addition of different salts $\left(\mathrm{NaCl}\right.$ and $\left.\mathrm{Na}_{2} \mathrm{SO}_{4}\right)$ from the model solution with relatively high efficiencies. Unfortunately, because of the presence of salts, chelating agents, by-products, or surfactants in real wastewaters, the enzymatic degradation of dyes must be supported by other, effective methods of removing impurities [5]. The combination of sorption and biodegradation methods may increase the efficiency of degradation of selected dyes as it was previously reported by Roy et al., who immobilized bacteria from the genus of Pseudomonas onto fly ash. Using this system, it was possible to degrade over $98 \%$ of Reactive Yellow 145 dye from aqueous solution [18]. Wangpradit also used a bimodal degradation mechanism to remove Reactive Blue 19, 160 and 198 dyes from aqueous solutions. Lentinus polychrous, producing laccase and manganese peroxidase, was covered with chitosan. This system allowed sorption of dyes by chitosan and simultaneous effective enzymatic biodegradation [19]. On the other hand, inorganic oxides materials such as $\mathrm{MnO}_{2}, \mathrm{ZnO}$ [20], graphene oxide [21], and $\mathrm{Al}_{2} \mathrm{O}_{3}$ [22] could be used for effective laccase immobilization and dye removal. However, the most frequently applied inorganic support for laccase immobilization and dye degradation is various forms of silica, such as mesoporous silica, fumed silica, sol-gel silica [23]. In addition, inorganic based composite materials, for instance macroporous $\mathrm{SiO}_{2} / \mathrm{ZnO}$ nanowires [24] and $\mathrm{SiO}_{2} / \mathrm{Fe}_{3} \mathrm{O}_{4}$ magnetic nanoparticles [25] have been previously used as support for laccase immobilization for environmental protection. From this point of view, particularly interesting as support materials for laccase immobilization are $\mathrm{TiO}_{2}-\mathrm{ZrO}_{2}$ and $\mathrm{TiO}_{2}-\mathrm{ZrO}_{2}-\mathrm{SiO}_{2}$ oxide materials. The advantages of these materials, such as great sorption properties, the presence of numerous of hydroxyl groups, highly developed surface area, uncomplicated and cost-effective synthesis [26], reveal that these materials might be used for the removal of impurities by simultaneous catalytic degradation and direct adsorption by the $\mathrm{TiO}_{2}-\mathrm{ZrO}_{2}$ and $\mathrm{TiO}_{2}-\mathrm{ZrO}_{2}-\mathrm{SiO}_{2}$.

In the presented study, the removal efficiency of Alizarin Red S, Remazol Brilliant Blue $\mathrm{R}$ (antraquinone dyes), Reactive Black 5 (diazo dye), and their mixture was determined under different process conditions, such as temperature, $\mathrm{pH}$, concentration of dyes solution, using laccase immobilized onto $\mathrm{TiO}_{2}-\mathrm{ZrO}_{2}$, and $\mathrm{TiO}_{2}-\mathrm{ZrO}_{2}-\mathrm{SiO}_{2}$ oxide systems. The efficient synthesis of oxide systems was 
confirmed by results of scanning electron microscopy (SEM), transmission electron microscopy (TEM), X-ray diffraction method (XRD), porous structure characterization and Fourier transform infrared spectroscopy (FTIR). The obtained biocatalytic systems were characterized by determining the amount of the immobilized enzyme and kinetic parameters as well as storage stability and reusability. Chemical oxygen demand (COD) was evaluated and compared before and after dye degradation to investigate how both binary and ternary oxide systems with immobilized laccase affect COD reduction in aqueous solutions of dyes.

\section{Results and Discussion}

\subsection{Supports Characterization}

The morphology and microstructure of the $\mathrm{TiO}_{2}-\mathrm{ZrO}_{2}$ and $\mathrm{TiO}_{2}-\mathrm{ZrO}_{2}-\mathrm{SiO}_{2}$ oxide materials were evaluated based on SEM and TEM observations (Figure 1). The obtained mixed oxide systems are characterized by non-spherical and irregular particles with nanometric size that tend to aggregation and agglomeration $[27,28]$. The $\mathrm{TiO}_{2}-\mathrm{ZrO}_{2}$ system is characterized by aggregates with diameters of around $10 \mu \mathrm{m}$, whereas $\mathrm{TiO}_{2}-\mathrm{ZrO}_{2}-\mathrm{SiO}_{2}$ material forms smaller aggregates, compared to a two-component oxide material, which size does not exceed $5 \mu \mathrm{m}$.

XRD patterns of the synthetic binary and ternary oxide systems confirm the formation of a crystalline material containing both titania and zirconia phases (see Figure 2). The XRD pattern of the $\mathrm{TiO}_{2}-\mathrm{ZrO}_{2}$ oxide system (Figure 2a) shows the characteristic diffraction peaks at $2 \theta=25.28^{\circ}$; $37.8^{\circ}$ and $48.05^{\circ}$, which correspond to the anatase phase (JCPDS No. 21-1272). The noticeable peak at $2 \theta=27.45^{\circ}$ is related to the rutile phase of $\mathrm{TiO}_{2}$ (JCPDS No. 21-1279). Moreover, the diffraction peaks at $2 \theta=30.44^{\circ}$ and $32.61^{\circ}$ correspond to the orthorhombic $\mathrm{ZrTiO}_{4}$ phase (JCPDS, No. 34-0415). Moreover, the XRD pattern of the obtained material exhibited the characteristic peaks (with low intensity) at $2 \theta=38.54^{\circ} ; 55.4^{\circ} ; 62.84^{\circ} ; 68.9^{\circ}$ and $75.04^{\circ}$, which are ascribed to the monoclinic phase of $\mathrm{ZrO}_{2}$ (JCPDS, No. 37-17484). Furthermore, for analyzed samples the other characteristic peaks for anatase, rutile and $\mathrm{ZrTiO}_{4}$ were also observed in the XRD pattern. The XRD pattern of ternary oxide system contains the similar diffraction peaks as were observed for $\mathrm{TiO}_{2}-\mathrm{ZrO}_{2}$ sample (Figure $2 \mathrm{~b}$ ). For $\mathrm{TiO}_{2}-\mathrm{ZrO}_{2}-\mathrm{SiO}_{2}$ sample, the addition of small amounts of silica in the preparation of ternary oxide materials, leads to obtained material in which the characteristic peak of rutile at $2 \theta=27.45^{\circ}$ disappeared, and reflection corresponded to the orthorhombic $\mathrm{ZrTiO}_{4}$ phase at $2 \theta=30.44^{\circ}$, a noticeable decrease.

The results of low-temperature $\mathrm{N}_{2}$ sorption isotherms of synthesized binary and ternary oxide systems are illustrated in Figure 3a. The isotherm measured for the $\mathrm{TiO}_{2}-\mathrm{ZrO}_{2}-\mathrm{SiO}_{2}$ oxide system was classified as type IV with hysteresis loops of type $\mathrm{H} 4$. The calculated BET surface area of the synthetic $\mathrm{TiO}_{2}-\mathrm{ZrO}_{2}-\mathrm{SiO}_{2}$ oxide material is $47.1 \mathrm{~m}^{2} / \mathrm{g}$. The total pore volume of analyzed sample is $0.082 \mathrm{~cm}^{3} / \mathrm{g}$ and the mean pore diameter is $5.1 \mathrm{~nm}$. As it was expected, the porous structure parameters of $\mathrm{TiO}_{2}-\mathrm{ZrO}_{2}$ sample showed that the analyzed material has a smaller surface area than the $\mathrm{TiO}_{2}-\mathrm{ZrO}_{2}-\mathrm{SiO}_{2}$ oxide system. The BET surface area of $\mathrm{TiO}_{2}-\mathrm{ZrO}_{2}$ sample is $19.3 \mathrm{~m} / \mathrm{g}$, its total pore volume is $0.121 \mathrm{~cm}^{3} / \mathrm{g}$ and its mean pore diameter is $22.8 \mathrm{~nm}$. The low-temperature $\mathrm{N}_{2}$ sorption isotherms estimated for $\mathrm{TiO}_{2}-\mathrm{ZrO}_{2}$ sample are classified as type II, with hysteresis loops of type $\mathrm{H} 3$.

To verify of the effective forming of the oxide systems, and to determine the surface functional groups, Fourier-transform infrared spectroscopy was used. FTIR spectra of both oxide systems (Figure $3 b$ ) possess characteristic signals, related to the similar oxide structure of both materials, which have their maxima at the wavenumber of $3480 \mathrm{~cm}^{-1}(v-\mathrm{OH})$ and around $600 \mathrm{~cm}^{-1}$ (broad peak covering signals characteristic for $\delta-\mathrm{ZrO}, v \mathrm{O}-\mathrm{Ti}-\mathrm{O}$, and $\delta \equiv \mathrm{Ti}-\mathrm{O}$. In addition, in the FTIR spectrum of the $\mathrm{TiO}_{2}-\mathrm{ZrO}_{2}-\mathrm{SiO}_{2}$ composite are visible characteristic peaks at $1540 \mathrm{~cm}^{-1}(v \equiv \mathrm{Ti}-\mathrm{O}-\mathrm{Si} \equiv)$ and $1080 \mathrm{~cm}^{-1}$ ( $\equiv \mathrm{Si}-\mathrm{O}-\mathrm{Si} \equiv$ ). The presence of the above signals indirectly confirms the effectiveness of the proposed technique for the synthesis of the inorganic oxide materials. Moreover, it should be emphasized that the presence of the hydroxyl groups on the surface and the morphological structure 
of the obtained systems enhances its application as a support material for enzyme immobilization and dye sorption [29].

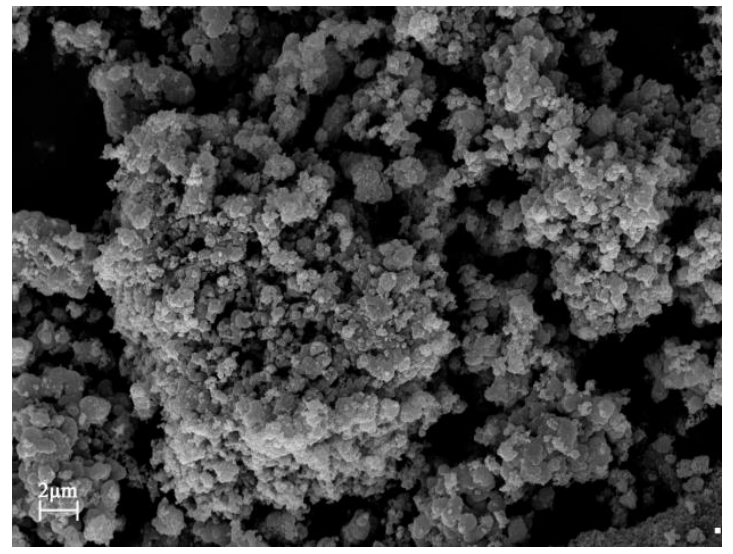

(a)

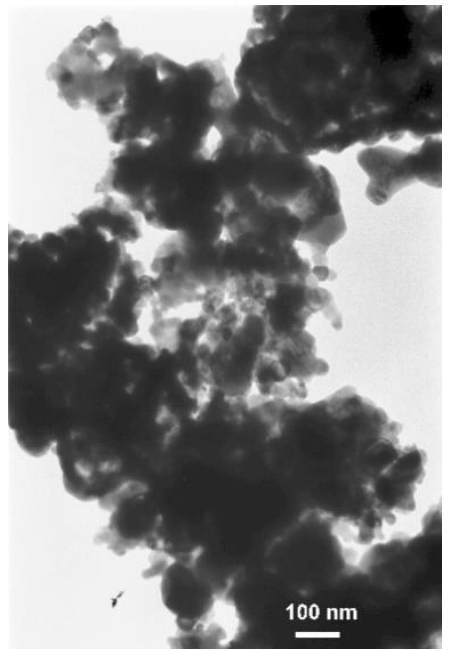

(c)

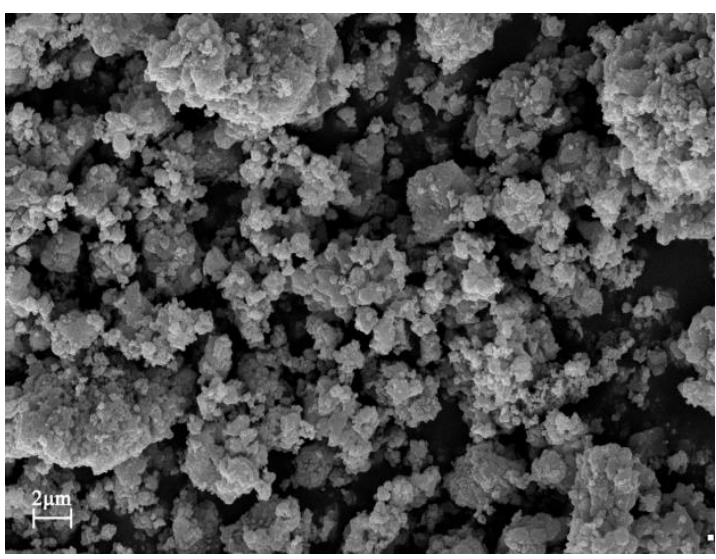

(b)

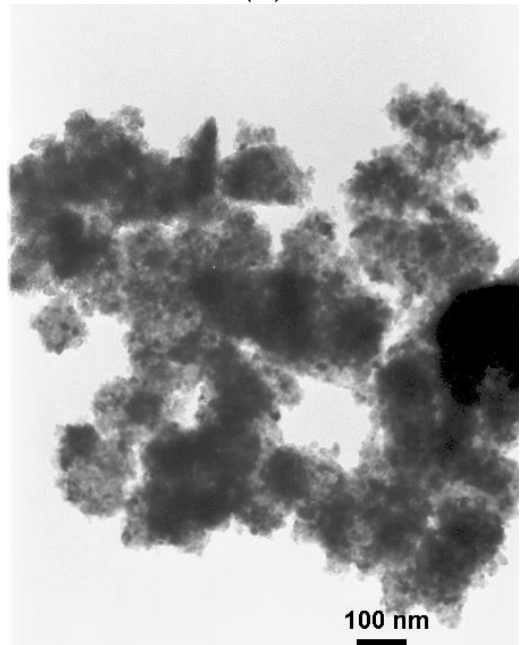

(d)

Figure 1. Scanning electron microscope (SEM) and transmission electron microscope (TEM) photos of: $(\mathbf{a}, \mathbf{c})$ pure $\mathrm{TiO}_{2}-\mathrm{ZrO}_{2}$ and $(\mathbf{b}, \mathbf{d})$ pure $\mathrm{TiO}_{2}-\mathrm{ZrO}_{2}-\mathrm{SiO}_{2}$ oxide materials.

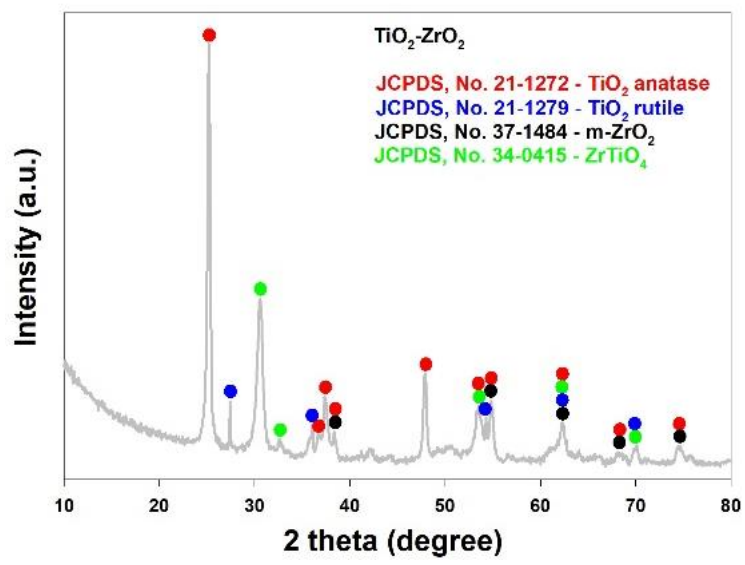

(a)

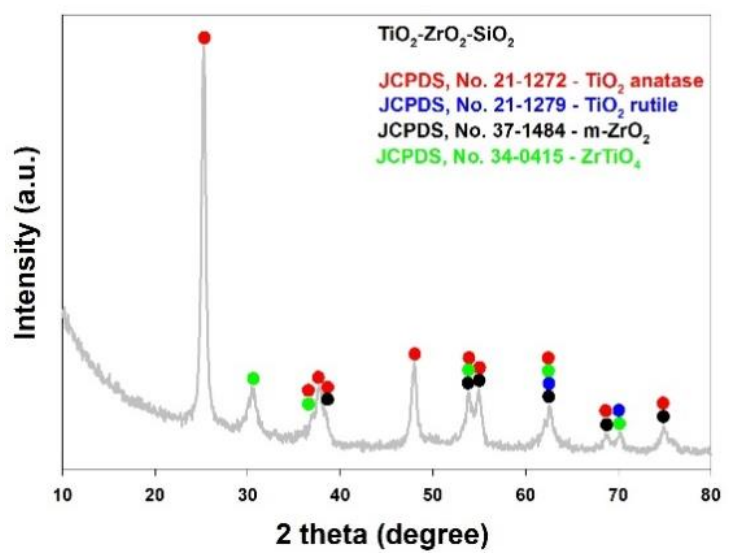

(b)

Figure 2. X-ray diffraction patterns of: (a) pure $\mathrm{TiO}_{2}-\mathrm{ZrO}$ and (b) pure $\mathrm{TiO}_{2}-\mathrm{ZrO}_{2}-\mathrm{SiO}_{2}$. 


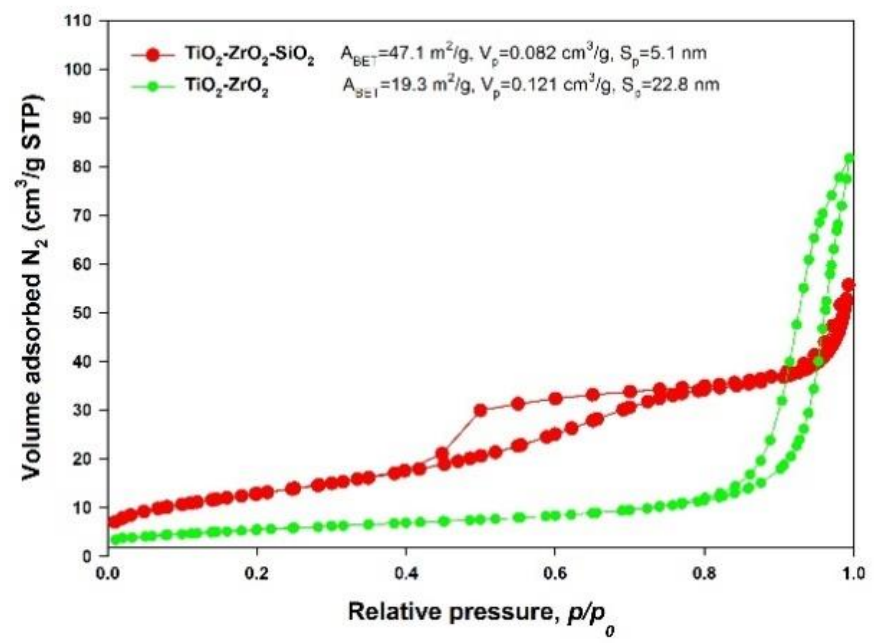

(a)

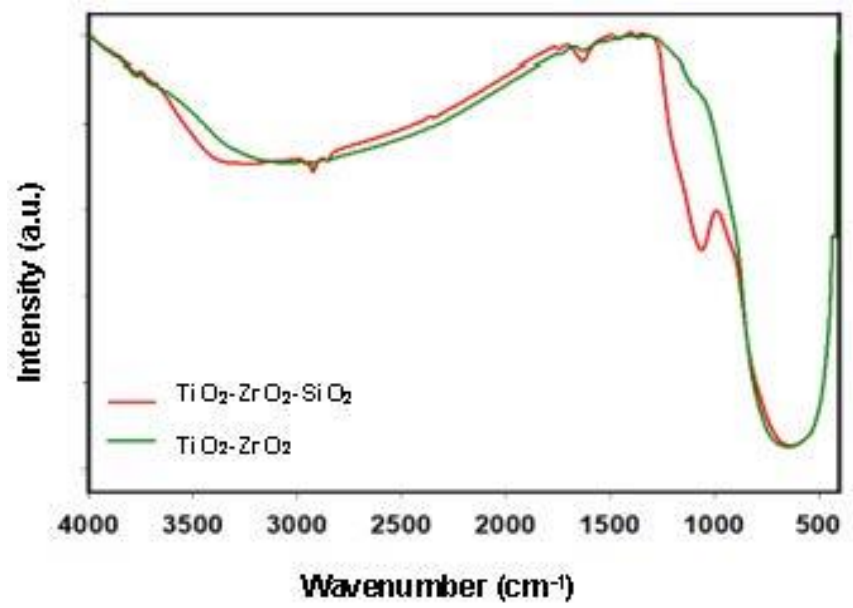

(b)

Figure 3. $\mathrm{N}_{2}$ adsorption/desorption isotherms (a) and Fourier-transform infrared (FTIR) spectra (b) of the synthesized materials.

\subsection{Characterization of the Biocatalytic Systems Obtained}

High immobilization efficiency, $83 \%$ and $96 \%$ for $\mathrm{TiO}_{2}-\mathrm{ZrO}_{2}$ and $\mathrm{TiO}_{2}-\mathrm{ZrO}_{2}-\mathrm{SiO}_{2}$, respectively, confirms the effective enzyme deposition onto obtained oxide systems. As it was previously mentioned, the used materials possess many functional moieties, mainly hydroxyl groups, which determine high immobilization efficiency. To investigate the changes in the laccase affinity to substrate before and after immobilization, kinetic parameters such as the Michaelis-Menten constant $\left(K_{m}\right)$ and maximum reaction rate $\left(V_{\max }\right)$ were calculated (Table 1$)$. The $K_{m}$ value of the free enzyme was $0.057 \mathrm{mM}$, while for laccase immobilized on $\mathrm{TiO}_{2}-\mathrm{ZrO}_{2}$ and $\mathrm{TiO}_{2}-\mathrm{ZrO}_{2}-\mathrm{SiO}_{2}$ was $0.108 \mathrm{mM}$ and $0.124 \mathrm{mM}$, respectively. Lower values of $V_{\max }$ were obtained for $\mathrm{TiO}_{2}-\mathrm{ZrO}_{2}$-laccase $(0.036 \mathrm{U} / \mathrm{mg})$ and for $\mathrm{TiO}_{2}-\mathrm{ZrO}_{2}-\mathrm{SiO}_{2}$-laccase $(0.029 \mathrm{U} / \mathrm{mg})$ than for the free enzyme $(0.046 \mathrm{U} / \mathrm{mg})$. The higher $K_{m}$ values for systems with immobilized laccase, compared to the native enzyme, and hence lower $V_{\max }$, may be caused by the formation of steric hindrances, which results in blocking of the active sites of the enzyme and limited transport of substrates, as previously reported [30-32]. However, the most pronounced changes in the values of the kinetic parameters were noticed for the $\mathrm{TiO}_{2}-\mathrm{ZrO}_{2}-\mathrm{SiO}_{2}$ after laccase attachment. Other scientists also have immobilized laccase on metal oxides to use them for dye degradation. By contrast, Rani et al. immobilized laccase on transition metal oxide nanomaterials and used the obtained biocatalytic systems for the degradation of Alizarin Red S. Among the $\mathrm{MO}_{\mathrm{x}}$-laccase systems used by them, such as $\mathrm{ZnO}$-laccase and $\mathrm{MnO}_{2}$-laccase, the zinc oxide system possessed the 
highest value of $K_{m}(2.75 \mathrm{mM})$, and significantly higher value of $V_{\max }$ parameter (146 U/mg) [20]. In addition, $\mathrm{Xu}$ et al. used the laccase immobilized onto graphene oxide to degrade Reactive Brilliant Blue, Methyl Orange, and Crystal Violet [21]. The immobilized enzyme was characterized by the maximal reaction rate of $0.108 \mathrm{U} / \mathrm{mg}$.

Table 1. Kinetic parameters of free and immobilized enzyme, amount of immobilized enzyme, and immobilization yield.

\begin{tabular}{cccc}
\hline Kinetic Parameters and Immobilization Data & Free Laccase & $\mathbf{T i O}_{\mathbf{2}}-\mathbf{Z r O}_{\mathbf{2}}$-Laccase & $\mathbf{T i O}_{\mathbf{2}}-\mathbf{Z r O}_{\mathbf{2}}-\mathbf{S i O}_{\mathbf{2}}$-Laccase \\
\hline$K_{m}(\mathrm{mM})$ & $0.057 \pm 0.004$ & $0.108 \pm 0.016$ & $0.124 \pm 0.019$ \\
$V_{\max }(\mathrm{U} / \mathrm{mg})$ & $0.046 \pm 0.006$ & $0.036 \pm 0.002$ & $0.029 \pm 0.003$ \\
Amount of enzyme $(\mathrm{mg} / \mathrm{g})$ & - & $83 \pm 3.2$ & $96 \pm 2.7$ \\
Immobilization yield (\%) & - & $83 \pm 3.4$ & $96 \pm 2.2$ \\
\hline
\end{tabular}

The storage stability of the free and immobilized enzyme was tested over 50 days and compared (Figure 4). The laccase immobilized onto $\mathrm{TiO}_{2}-\mathrm{ZrO}_{2}$ retained around $90 \%$ of its initial activity after 20 days and over $80 \%$ after 50 days of storage. By comparison, the protein immobilized onto $\mathrm{TiO}_{2}-\mathrm{ZrO}_{2}-\mathrm{SiO}_{2}$ retained $95 \%$ after 20 days and around $90 \%$ after 50 days of storage. As it was expected, storage stability of the free laccase was significantly lower, as the free enzyme retained only around $50 \%$ of its catalytic properties after 20 days and less than $15 \%$ after 50 days of storage, indicating that the storage stability of the immobilized enzyme is much higher than that of the free enzyme. This might be explained by the multipoint adsorption attachment of the laccase to the support surface that protects the three-dimensional structure of the laccase against the conformational changes caused by the reaction environment and storage, as reported earlier also by $\mathrm{Xu}$ et al. [33]. In our previous study, we immobilized laccase by adsorption on biopolymeric Hippospongia communis spongin-based scaffolds. After 50 days, immobilized laccase retained over $80 \%$ activity, compared to the initial one [34]. Thus, the obtained results of storage stability correspond with the results obtained previously.

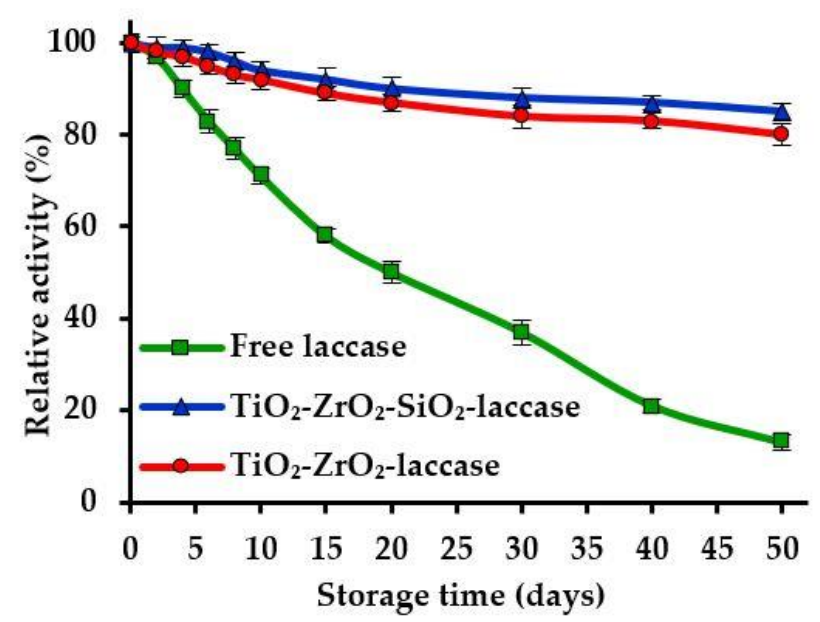

Figure 4. Storage stability of free and immobilized laccase after 50 days of storage time.

\subsection{Dye Removal}

\subsubsection{Dye Removal in the Presence of Oxide Materials with Inactivated Enzyme}

In the first step of the investigation, the sorption capacities of the obtained $\mathrm{TiO}_{2}-\mathrm{ZrO}_{2}$ and $\mathrm{TiO}_{2}-\mathrm{ZrO}_{2}-\mathrm{SiO}_{2}$ materials with thermally inactivated enzyme against solutions of Alizarin Red $\mathrm{S}$ (ARS), Remazol Brilliant Blue R (RBBR), and Reactive Black 5 (RB5) dyes at concentrations of 1, 5, and $10 \mathrm{mg} / \mathrm{L}$ were evaluated (see Table 2). It can be concluded that the sorption efficiency of dyes decreases with the increasing concentration of the dye solution. The same conclusion was deduced by Vignesh Kumar et al., who adsorbed Reactive Black 5 dye on the obtained coral-like hierarchical 
$\mathrm{MgO}$ incorporated fly ash composite [35]. However, it should be noted that in the case of a ternary system with a thermally inactivated enzyme, about $10 \%$ and $30 \%$ higher sorption efficiencies were achieved for RB5 and ARS, respectively, compared to a binary oxide material. Most likely, the presence of silicon oxide(IV) in a ternary oxide material increases the sorption properties of ARS and RB5 dyes. Moreover, the presence of numerous of functional groups in the $\mathrm{TiO}_{2}-\mathrm{ZrO}_{2}-\mathrm{SiO}_{2}$ material also increase its sorption capacity towards dyes [36]. On the other hand, higher sorption efficiency of RBBR dye by $\mathrm{TiO}_{2}-\mathrm{ZrO}_{2}$ might be explained by the fact that in binary oxide material molar ratio of $\mathrm{ZrO}_{2}$ is two times higher compared with ternary oxide material and, as it was previously reported by Myiamoto et al., $\mathrm{ZrO}_{2}$ exhibits high affinity to create interactions with single N-H bonds presented in the structure of RBBR [37]. It is worth to mention that there are many reports about the removal of dyes from aqueous solutions by sorption on various materials with different efficiency. For example, Rehman adsorbed Alizarin Red S onto alumina with the efficiency of around 70\% [12], while Kamaz, using activated sludge from municipal wastewater, adsorbed nearly $100 \%$ of Congo Red, Eriochrome Black T, and RBBR [38]. The results obtained by us allow to state that oxide materials can also be used for sorption of environmental pollutants such as dyes.

Table 2. Sorption efficiencies of dyes (Alizarin Red S (ARS), Remazol Brilliant Blue R (RBBR), Reactive Black 5 (RB5)) onto $\mathrm{TiO}_{2}-\mathrm{ZrO}_{2}$ and $\mathrm{TiO}_{2}-\mathrm{ZrO}_{2}-\mathrm{SiO}_{2}$ oxide materials with inactivated enzyme after $24 \mathrm{~h}$ of the process. The errors of all measurements do not exceed $5 \%$.

\begin{tabular}{|c|c|c|c|c|c|c|}
\hline \multirow{3}{*}{$\begin{array}{c}\text { Dye } \\
\text { Concentration } \\
(\mathrm{mg} / \mathrm{L})\end{array}$} & \multicolumn{6}{|c|}{ Sorption Efficiency (\%) } \\
\hline & \multicolumn{2}{|c|}{ ARS } & \multicolumn{2}{|c|}{ RBBR } & \multicolumn{2}{|c|}{ RB5 } \\
\hline & $\begin{array}{l}\mathrm{TiO}_{2}-\mathrm{ZrO}_{2-} \\
\text { Laccase }\end{array}$ & $\begin{array}{l}\mathrm{TiO}_{2}-\mathrm{ZrO}_{2}-\mathrm{SiO}_{2}- \\
\text { Laccase }\end{array}$ & $\begin{array}{l}\mathrm{TiO}_{2}-\mathrm{ZrO}_{2-} \\
\text { Laccase }\end{array}$ & $\begin{array}{l}\mathrm{TiO}_{2}-\mathrm{ZrO}_{2}-\mathrm{SiO}_{2}- \\
\text { Laccase }\end{array}$ & $\begin{array}{l}\mathrm{TiO}_{2}-\mathrm{ZrO}_{2-} \\
\text { Laccase }\end{array}$ & $\begin{array}{l}\mathrm{TiO}_{2}-\mathrm{ZrO}_{2}-\mathrm{SiO}_{2}- \\
\text { Laccase }\end{array}$ \\
\hline 1 & 74 & 100 & 76 & 46 & 24 & 37 \\
\hline 5 & 28 & 51 & 48 & 48 & 15 & 23 \\
\hline 10 & 0 & 25 & 46 & 28 & 6 & 12 \\
\hline
\end{tabular}

\subsubsection{Effect of a Concentration of Dyes Solution on Removal Efficiencies}

After determining the sorption capacity of the produced materials with the inactivated enzyme, the influence of various parameters (dye concentration, $\mathrm{pH}$, temperature) on the efficiency of dye degradation was also determined.

To study the effect of the dye concentration, solution of ARS, RBBR and RB5 dyes at concentrations ranging from 1 to $10 \mathrm{mg} / \mathrm{L}$ were used for the biodegradation using both $\mathrm{TiO}_{2}-\mathrm{ZrO}_{2}$ and $\mathrm{TiO}_{2}-\mathrm{ZrO}_{2}-\mathrm{SiO}_{2}$ carriers with immobilized laccase (Figure 5). The analysis of the obtained results allows us to state that the higher the concentration of the dye, the lower the degradation rate. Based on the presented results, it can be concluded that using the $\mathrm{TiO}_{2}-\mathrm{ZrO}_{2}-\mathrm{SiO}_{2}$-laccase system, it is possible to completely remove ARS, even from the solution at the highest concentration $(10 \mathrm{mg} / \mathrm{L})$. The use of the $\mathrm{TiO}_{2}-\mathrm{ZrO}_{2}$-laccase system results in lower ARS removal efficiency as compared to $\mathrm{TiO}_{2}-\mathrm{ZrO}_{2}-\mathrm{SiO}_{2}$-laccase, which is $83 \%$ and $60 \%$ for a $5 \mathrm{mg} / \mathrm{L}$ and $10 \mathrm{mg} / \mathrm{L}$ solution, respectively. This is governed by the presence of $\mathrm{SiO}_{2}$ in a three-component material. The addition of silica increases the efficiency of the immobilization of laccase on the carrier, which leads to an increase in the efficiency of the removal of Alizarin Red S dye [39]. These results are in agreement with a study by $\mathrm{Li}$ et al., who immobilized laccase onto $\mathrm{ZnO} / \mathrm{SiO}_{2}$ material and degraded Remazol Brilliant Blue B and Acid Blue 25 from an aqueous solution at a concentration $0.1 \mathrm{~mol} / \mathrm{L}$. The researchers also suggested that the presence of $\mathrm{SiO}_{2}$ enabled the effective immobilization of the enzyme and increased the effective degradation of selected dyes [40]. In the case of a $1 \mathrm{mg} / \mathrm{L}$ RBBR dye solution, degradation occurs at $100 \%$, as for a $10 \mathrm{mg} / \mathrm{L}$ RBBR solution, it is about $70 \%$ for both systems obtained after immobilization. For RB5 dye, there was significantly higher efficiency of dye removal than adsorption, which is evidence for the enzyme assisted degradation process. For a $1 \mathrm{mg} / \mathrm{L}$ solution, the degradation occurs with $100 \%$ efficiency, regardless of the applied biocatalytic system, whereas for a $10 \mathrm{mg} / \mathrm{L}$ dye it reaches about $47 \%$ for the $\mathrm{TiO}_{2}-\mathrm{ZrO}_{2}-\mathrm{SiO}_{2}-$ laccase system and less than $10 \%$ for the $\mathrm{TiO}_{2}-\mathrm{ZrO}_{2}$-laccase. The reduction of the degradation efficiency of 
the systems after immobilization along with the increase of the concentration of the dye solution (particularly observed in case of RBBR and RB5) is most probably caused by the more complicated structure of these dyes and an insufficient amount of laccase immobilized on the surface of both carriers, which prevents complete dye removal from the solutions at higher concentrations.

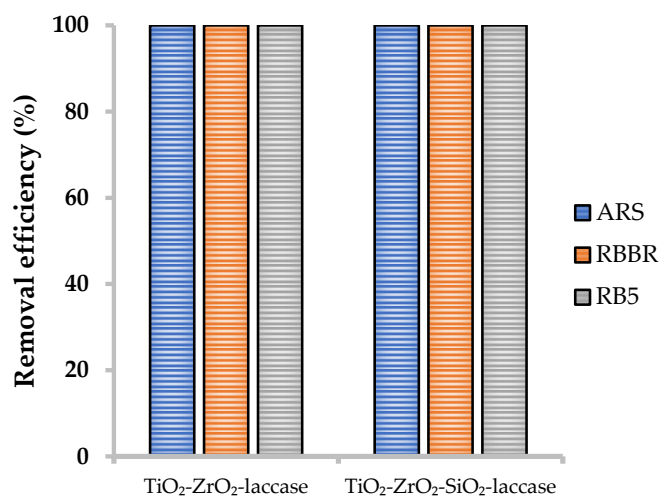

(a)

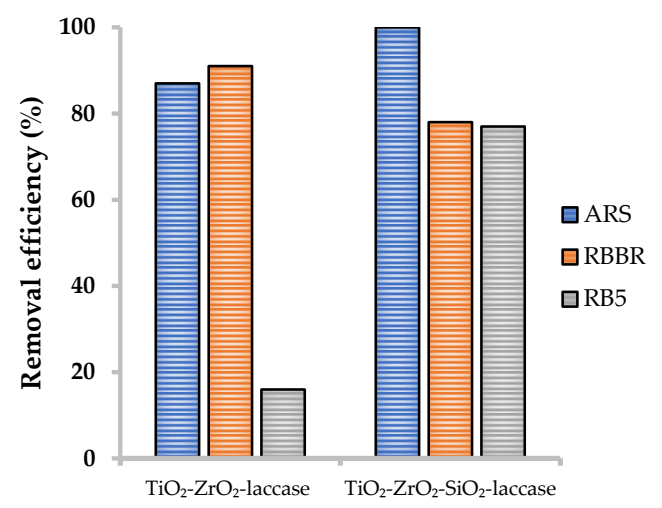

(b)

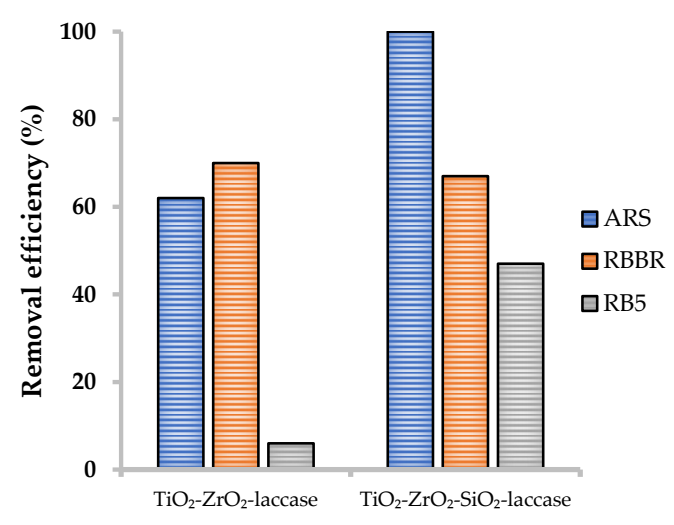

(c)

Figure 5. Effect of concentration of ARS, RBBR, an RB5 solutions at concentrations: (a) $1 \mathrm{mg} / \mathrm{L}$; (b) $5 \mathrm{mg} / \mathrm{L}$; (c) $10 \mathrm{mg} / \mathrm{L}$, on its removal efficiencies. The errors of all measurements do not exceed $5 \%$.

\subsubsection{Effect of $\mathrm{pH}$ of Dyes Solution on Removal Efficiencies}

In order to determine the effect of $\mathrm{pH}$ on the degradation of ARS, RBBR, and RB5 dyes using obtained biocatalytic systems, a $5 \mathrm{mg} / \mathrm{L}$ dye solution was selected and tests were carried out at $\mathrm{pH}$ ranging from 4 to 6 (Table 3). The obtained data indicate that the $\mathrm{pH}$ does not significantly affect the efficiency of dye removal. The ARS dye in the tested $\mathrm{pH}$ range has the highest removal efficiency. Using the $\mathrm{TiO}_{2}-\mathrm{ZrO}_{2}-\mathrm{SiO}_{2}$-laccase system, it reached $100 \%$, as the dye removal by $\mathrm{TiO}_{2}-\mathrm{ZrO}_{2}$-laccase was over $85 \%$ in all of the $\mathrm{pH}$ values. A similar trend can be seen for the other two dyes, where the differences between the highest and lowest degradation efficiency with a given system do not exceed $5 \%$. For RBBR dye, the removal efficiency was the highest at $\mathrm{pH} 5(91 \%)$ using the $\mathrm{TiO}_{2}-\mathrm{ZrO}_{2}-$ laccase system and its whole tested $\mathrm{pH}$ range differs by $4 \%$, between the highest and lowest. The removal rate of $\mathrm{RBBR}$ was lower using the $\mathrm{TiO}_{2}-\mathrm{ZrO}_{2}-\mathrm{SiO}_{2}$-laccase system $(78 \%$ at $\mathrm{pH} 5)$ and at $\mathrm{pH} 4$ and $\mathrm{pH} 6$ differ by $2 \%$. The biggest difference in the degradation efficiency, among the tested $\mathrm{pH}$, can be seen in removing the $\mathrm{RB} 5$ dye by the $\mathrm{TiO}_{2}-\mathrm{ZrO}_{2}$-laccase system, which is $10 \%$, indicating that laccase immobilized onto a binary oxide system is more affected by the changes of $\mathrm{pH}$. It can be noted that laccase immobilized onto synthesized oxide materials can work at different $\mathrm{pH}$ values and efficiently degrade selected dyes. In contrast, free laccase showed its maximal activity at $\mathrm{pH} 5$ and gradually lost its properties with $\mathrm{pH}$ changes (data not presented). These results show that the stability of the laccase after immobilization against $\mathrm{pH}$ conditions was improved, mainly due to the protection of the enzyme 
by the support material [41]. These results stay in agreement with the data presented by Rangelov and Nicell. In their study, free laccase possesses the highest activity at $\mathrm{pH} 5$, however, after immobilization the $\mathrm{pH}$ range for high enzyme activity was extended [42].

Table 3. Removal efficiencies of dyes from solutions at different $\mathrm{pH}$ after $24 \mathrm{~h}$ of the process (concentration of dye solution $5 \mathrm{mg} / \mathrm{L}$, temperature $25^{\circ} \mathrm{C}$ ). The errors of all measurements do not exceed $5 \%$.

\begin{tabular}{|c|c|c|c|c|c|c|}
\hline \multirow{3}{*}{$\mathrm{pH}$} & \multicolumn{6}{|c|}{ Removal Efficiency (\%) } \\
\hline & \multicolumn{2}{|c|}{ ARS } & \multicolumn{2}{|c|}{ RBBR } & \multicolumn{2}{|c|}{ RB5 } \\
\hline & $\begin{array}{l}\mathrm{TiO}_{2}-\mathrm{ZrO}_{2-}- \\
\text { Laccase }\end{array}$ & $\begin{array}{c}\mathrm{TiO}_{2}-\mathrm{ZrO}_{2}-\mathrm{SiO}_{2}- \\
\text { Laccase }\end{array}$ & $\begin{array}{l}\mathrm{TiO}_{2}-\mathrm{ZrO}_{2-} \\
\text { Laccase }\end{array}$ & $\begin{array}{c}\mathrm{TiO}_{2}-\mathrm{ZrO}_{2}-\mathrm{SiO}_{2}- \\
\text { Laccase }\end{array}$ & $\begin{array}{l}\mathrm{TiO}_{2}-\mathrm{ZrO}_{2-} \\
\text { Laccase }\end{array}$ & $\begin{array}{c}\mathrm{TiO}_{2}-\mathrm{ZrO}_{2}-\mathrm{SiO}_{2}- \\
\text { Laccase }\end{array}$ \\
\hline 4 & 90 & 100 & 87 & 75 & 11 & 76 \\
\hline 5 & 87 & 100 & 91 & 78 & 16 & 77 \\
\hline 6 & 86 & 100 & 90 & 76 & 6 & 75 \\
\hline
\end{tabular}

\subsubsection{Effect of Temperature of Dyes Solution on Removal Efficiencies}

The effect of temperature on the removal efficiency of ARS, RBBR, and RB5 was examined at a temperature of 5,25 , and $50{ }^{\circ} \mathrm{C}$ in $\mathrm{pH} 5$ using dyes solution at concentration of $5 \mathrm{mg} / \mathrm{L}$ (Table 4). The highest removal efficiencies for each of the dyes (up to $100 \%$ for ARS) were observed at $25^{\circ} \mathrm{C}$. At $5{ }^{\circ} \mathrm{C}$, all dyes, regardless of the used biocatalytic system, were degraded about $15 \%$; less effective compared to $25{ }^{\circ} \mathrm{C}$. However, raising the temperature up to $50{ }^{\circ} \mathrm{C}$ results in about a $10 \%$ decrease in the removal of ARS and RBBR dyes. In the case of RB5, irrespectively of the used biocatalytic system, degradation efficiencies were even up to $30 \%$ lower than at $25^{\circ} \mathrm{C}$. The relatively high activity of laccase at $50{ }^{\circ} \mathrm{C}$ is probably due to the fact that oxide supports stabilize the laccase structure and prevent against its thermal inactivation even at high temperature. Regarding the degradation of dyes at $5{ }^{\circ} \mathrm{C}$, a significant reduction in process efficiency can be noticed. This fact is caused by conformational changes in the laccase structure [43] and a reduction of enzymatic activity at low temperatures, as was previously reported [44]. Nevertheless, it is worth mentioning that even at high temperature, degradation of the selected dyes occurs more efficiently than simple sorption, which means that the enzyme works and its activity is visible even at 5 and $50{ }^{\circ} \mathrm{C}$. Reda et al. also investigated the effect of temperature on the degradation efficiency of synthetic dyes (including Methyl Red, Congo Red, Trypan Blue, RBBR and Aniline Blue) using laccase immobilized on various supports, such as Ca-alginate, agarose-agar, alginate-gelatin mixed gel, and polyacrylamide gel [45]. The temperature range at which the tests were performed was from 30 to $60{ }^{\circ} \mathrm{C}$. By contrast to our study, the highest degradation efficiency was obtained at $50{ }^{\circ} \mathrm{C}$. This is explained by the fact that the encapsulation immobilization maintains the stability of the enzyme and its active structure, and thus the possibility of using immobilized laccase in the industry, especially in the textile industry, is an important consideration.

Although the obtained oxide materials possess good sorption properties, higher dye removal efficiency has been obtained using immobilized enzymes. This indicates a dual sorption/enzymatic action mechanism of dyes degradation. Similar observations were made also by Ramírez-Montoya et al., who investigated the effectiveness of Acid Orange 7 degradation [46]. In their study, laccase immobilized onto different lignocellulosic wastes was used and achieved total dye removal by enzymatic biodegradation assisted by adsorption on the selected carrier. 
Table 4. Removal efficiencies of dyes from solutions at different temperature conditions after $24 \mathrm{~h}$ of the process (concentration of dyes solution $5 \mathrm{mg} / \mathrm{L}, \mathrm{pH}$ ). The errors of all measurements do not exceed $5 \%$.

\begin{tabular}{|c|c|c|c|c|c|c|}
\hline \multirow{3}{*}{ Temp. $\left({ }^{\circ} \mathrm{C}\right)$} & \multicolumn{6}{|c|}{ Removal Efficiency (\%) } \\
\hline & \multicolumn{2}{|c|}{ ARS } & \multicolumn{2}{|c|}{ RBBR } & \multicolumn{2}{|c|}{ RB5 } \\
\hline & $\begin{array}{l}\mathrm{TiO}_{2}-\mathrm{ZrO}_{2}- \\
\text { Laccase }\end{array}$ & $\begin{array}{c}\mathrm{TiO}_{2}-\mathrm{ZrO}_{2}-\mathrm{SiO}_{2}- \\
\text { Laccase }\end{array}$ & $\begin{array}{l}\mathrm{TiO}_{2}-\mathrm{ZrO}_{2-} \\
\text { Laccase }\end{array}$ & $\begin{array}{l}\mathrm{TiO}_{2}-\mathrm{ZrO}_{2}-\mathrm{SiO}_{2}- \\
\text { Laccase }\end{array}$ & $\begin{array}{l}\mathrm{TiO}_{2}-\mathrm{ZrO}_{2}- \\
\text { Laccase }\end{array}$ & $\begin{array}{l}\mathrm{TiO}_{2}-\mathrm{ZrO}_{2}-\mathrm{SiO}_{2}- \\
\text { Laccase }\end{array}$ \\
\hline 5 & 74 & 87 & 70 & 62 & 7 & 42 \\
\hline 25 & 87 & 100 & 91 & 78 & 16 & 77 \\
\hline 50 & 83 & 91 & 82 & 66 & 7 & 49 \\
\hline
\end{tabular}

\subsubsection{Removal of Dyes from Dye Mixtures}

After determining the optimal degradation conditions for individual dyes, the ARS, RBBR, and RB5 model mixture solution was also undertaken to remove experiments using the produced biocatalytic systems, due to the presence of these dyes in the sewage of the textile industry. The total concentration of degraded dyes was $5 \mathrm{mg} / \mathrm{L}$. The dyes mixture degradation was carried out at $\mathrm{pH} 5$ and $25^{\circ} \mathrm{C}$. The UV-Vis spectra were made over a wavelength range from $800 \mathrm{~nm}$ to $300 \mathrm{~nm}$ (see Figure 6) to establish the maximum absorbance for individual dye. The obtained spectra show the progress of the mixture decolorization after 12 and $24 \mathrm{~h}$ of the degradation process. It can be seen that the $\mathrm{TiO}_{2}-\mathrm{ZrO}_{2}-\mathrm{SiO}_{2}$ with immobilized enzyme caused better removal of dye mixtures, comparing with the $\mathrm{TiO}_{2}-\mathrm{ZrO}_{2}$-laccase system, after $12 \mathrm{~h}$ of degradation. However, after $24 \mathrm{~h}$ of the decolorization, both binary and ternary systems with laccase exhibited similar degradation efficiency. It should be added that according to Faraco et al., during the degradation of the model dyes solution new, less toxic products were created [5], although on the spectra there are no new peaks related to these compounds.

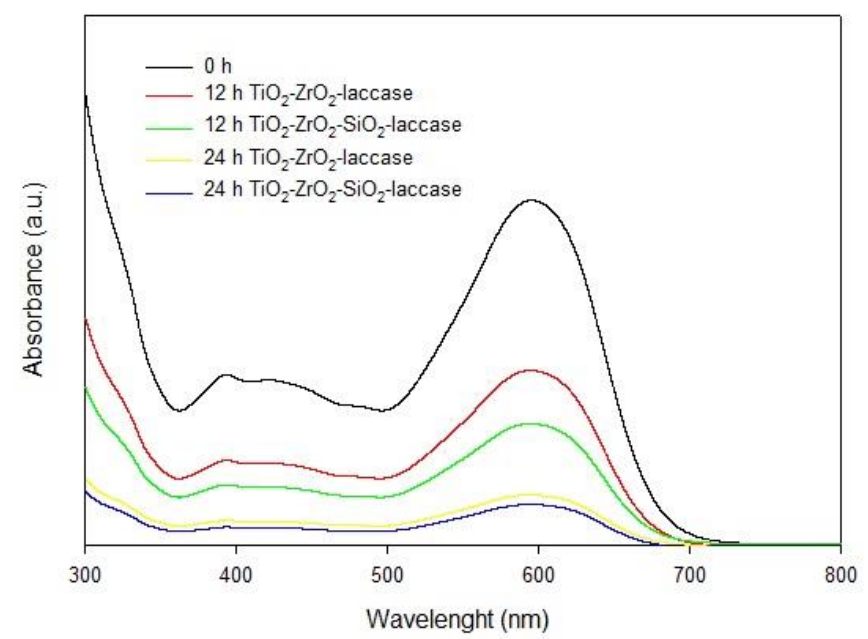

Figure 6. Removal of dyes from the mixed solution using the $\mathrm{TiO}_{2}-\mathrm{ZrO}_{2}$-laccase and $\mathrm{TiO}_{2}-\mathrm{ZrO}_{2}$ $\mathrm{SiO}_{2}$-laccase systems.

\subsubsection{Reusability of the Biocatalytic Systems Obtained}

Reusability plays a crucial role in enzyme immobilization. Thanks to this feature, the biocatalytic system can be reused, and hence the operational costs of the processes can be reduced, which is an important aspect in the industry [47]. In the present study, the removal efficiency of ARS, RBBR, and $\mathrm{RB} 5$ and a mixture of these three dyes in the presence of $\mathrm{TiO}_{2}-\mathrm{ZrO}_{2}$ and $\mathrm{TiO}_{2}-\mathrm{ZrO}_{2}-\mathrm{SiO}_{2}$ systems with an immobilized biocatalyst were evaluated over five successive degradation cycles (Figure 7). The obtained results indicate that the $\mathrm{TiO}_{2}-\mathrm{ZrO}_{2}$-laccase and $\mathrm{TiO}_{2}-\mathrm{ZrO}_{2}-\mathrm{SiO}_{2}$-laccase systems degrade the ARS dye with efficiencies around $60 \%$ and above $90 \%$, respectively. What is more, it should be noted that the degradation efficiency of ARS decreases during the first three catalytic cycles, and then 
it is fixed at a constant level. The obtained results confirm that it is also possible to reuse systems after immobilization, during the removal of RBBR. However, each subsequent cycle is characterized by a drop in degradation efficiency by about $10 \%$. The $\mathrm{TiO}_{2}-\mathrm{ZrO}_{2}$-laccase system keeps better catalytic properties because after five reaction cycles it was possible to remove about $40 \%$ of the dye, whereas the $\mathrm{TiO}_{2}-\mathrm{ZrO}_{2}-\mathrm{SiO}_{2}$-laccase system allowed for biodegradation of about $20 \%$ of RBBR. It can also be concluded that the reuse of both enzymatic systems in subsequent biodegradation cycles caused a decrease in decolorization of the Reactive Black 5 (Figure 7c). However, it should be noted that for the $\mathrm{TiO}_{2}-\mathrm{ZrO}_{2}-\mathrm{SiO}_{2}$-laccase system, a total decrease of about $10 \%$ (from 80 to $70 \%$ ) was observed, as for the $\mathrm{TiO}_{2}-\mathrm{ZrO}_{2}$-laccase system a more significant drop was noticed, because after the five catalytic cycles, no degradation was observed. Regarding the dyes mixture, the best removal efficiency during the five cycles was obtained in the presence of $\mathrm{TiO}_{2}-\mathrm{ZrO}_{2}-\mathrm{SiO}_{2}$-laccase. It was about $70 \%$ after five cycles, where, comparing with $\mathrm{TiO}_{2}-\mathrm{ZrO}_{2}$-laccase system, there was about $40 \%$. This difference is probably due to the fact that in the mixed solution of dyes, two of them (ARS and RB5) more effectively are degraded in the presence of the $\mathrm{TiO}_{2}-\mathrm{ZrO}_{2}-\mathrm{SiO}_{2}$-laccase system, so that the whole solution is degraded more effectively within the biocatalytic system. Summarizing, the most likely reduction in degradation efficiency is related to the decrease in enzyme activity occurred due to the catalysis of subsequent transformation cycles. In addition, partial inhibition of the immobilized enzyme by products and substrates of the reaction, as well as its inactivation due to the $\mathrm{pH}$ and temperature conditions, might not be excluded [48]. Moreover, the partial elution of the enzyme from the support occurred, as after five consecutive removal cycles around 15 and over $25 \mathrm{mg}$ of the enzyme was eluted form $1 \mathrm{~g}$ of the $\mathrm{TiO}_{2}-\mathrm{ZrO}_{2}-\mathrm{SiO}_{2}$ and $\mathrm{TiO}_{2}-\mathrm{ZrO}_{2}$ support, respectively, irrespectively of the type of the used solution. In other study, Reda et al. immobilized laccase by entrapment method onto alginate-gelatin support. After seven catalytic cycles of synthetic dyes degradation, the biocatalytic system showed $65 \%$ activity compared to the initial one [40]. On the other hand, Ma et al. obtained $48 \%$ of degradation efficiency of synthetic dyes after 14 catalytic cycles for laccase immobilized on chitosan crosslinked with genipin [49]. The differences between the above tests and this study result from the use of various supports and the method of enzyme immobilization.

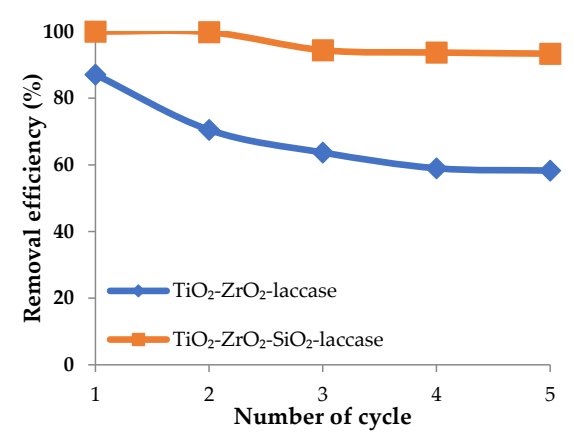

(a)

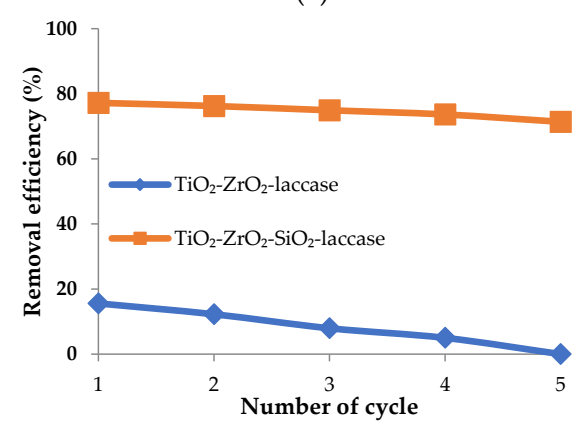

(c)

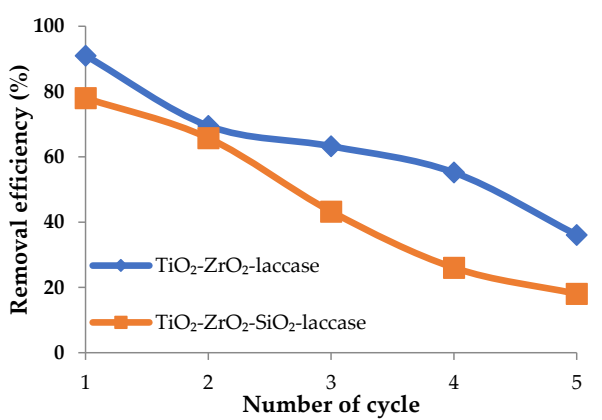

(b)

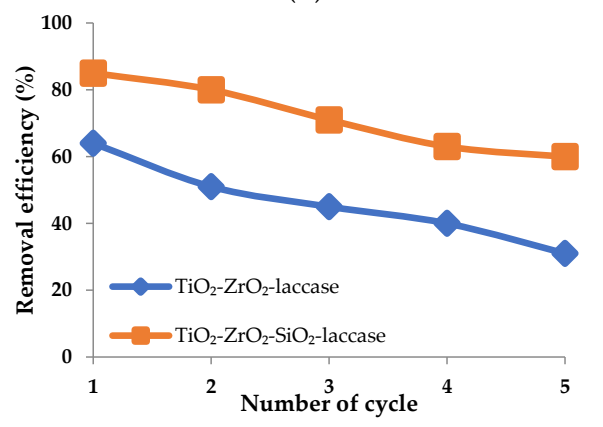

(d)

Figure 7. Removal efficiencies of: (a) ARS; (b) RRBR; (c) RB5; (d) mixture of dyes. Concentration of $5 \mathrm{mg} / \mathrm{L}$, temperature of $25^{\circ} \mathrm{C}$ duration of 1 cycle $-24 \mathrm{~h}$. The errors of all measurements do not exceed $5 \%$. 


\subsubsection{COD Determination}

The high chemical oxygen demand (COD) values in textile wastewater makes dyes difficult to remove, which is caused by the presence of organic substances, not only in the dyes themselves, but also in additives such as detergents $[15,50]$. It is worth mentioning that in each country there are special laws regarding the content of wastewater and their parameters released from industry. The most frequent are: chemical oxygen demand (COD), biochemical oxygen demand (BOD), or color [51]. In our study the COD determination was performed to investigate the extent of COD and its reduction after using the $\mathrm{TiO}_{2}-\mathrm{ZrO}_{2}$-laccase and $\mathrm{TiO}_{2}-\mathrm{ZrO}_{2}-\mathrm{SiO}_{2}$-laccase systems for the degradation of ARS, RBBR, RB5 and dyes mixture (Table 5). The highest degree of COD reduction was obtained for the dyes mixture, degraded in the presence of ternary system with immobilized laccase $(98.84 \%)$, while the lowest efficiency for RB5, removed by the $\mathrm{TiO}_{2}-\mathrm{ZrO}_{2}$-laccase system. Moreover, the results obtained for the rest of the dyes and biocatalytic systems are correlated with the results obtained after degradation of dye solution at a concentration of $5 \mathrm{mg} / \mathrm{L}$ under optimal process conditions. The relatively high COD reduction of selected dyes and dyes mixture can be caused by enzymatic biodegradation, sorption of dyes, and sorption of the products obtained after the treatment onto oxide materials. Comparing with other study, Paz et al. degraded textile dyes such as Coomassie Brilliant Blue G-250, Indigo Carmine, and Remazol Brilliant Blue R using Bacillus aryabhattai DC100, which produces ligninolytic enzymes such as laccases and/or peroxidases [51]. The highest reduction of COD occurred for Comassie Brilliant Blue G-250 and it was $43 \%$ after $48 \mathrm{~h}$ of degradation. The obtained results are prospective, because the degradation efficiency and COD reduction efficiency is relatively high. It, in consequence, leads to less organic matter being transferred to sewage treatment plants and/or surface water after previous simultaneous adsorption/enzymatic removal.

Table 5. Chemical oxygen demand (COD) determination of dyes after $24 \mathrm{~h}$ degradation in the presence of $\mathrm{TiO}_{2}-\mathrm{ZrO}_{2}$-laccase and $\mathrm{TiO}_{2}-\mathrm{ZrO}_{2}-\mathrm{SiO}_{2}$-laccase. Each of solution was at $5 \mathrm{mg} / \mathrm{L}$ concentration, pH 5 and temperature of $25^{\circ} \mathrm{C}$. The errors of all measurements do not exceed $5 \%$.

\begin{tabular}{ccc}
\hline Solution & Biocatalytic System & COD Reduction Efficiency (\%) \\
\hline \multirow{2}{*}{ ARS } & $\mathrm{TiO}_{2}-\mathrm{ZrO}_{2}$-laccase & 78.58 \\
& $\mathrm{TiO}_{2}-\mathrm{ZrO}_{2}-\mathrm{SiO}_{2}$-laccase & 84.66 \\
\hline \multirow{2}{*}{ RBBR } & $\mathrm{TiO}_{2}-\mathrm{ZrO}_{2}$-laccase & 71.52 \\
& $\mathrm{TiO}_{2}-\mathrm{ZrO}_{2}-\mathrm{SiO}_{2}$-laccase & 64.34 \\
\hline \multirow{2}{*}{ RB5 } & $\mathrm{TiO}_{2}-\mathrm{ZrO}_{2}$-laccase & 20.35 \\
& $\mathrm{TiO}_{2}-\mathrm{ZrO}_{2}-\mathrm{SiO}_{2}$-laccase & 87.65 \\
\hline \multirow{2}{*}{ Dyes mixture } & $\mathrm{TiO}_{2}-\mathrm{ZrO}_{2}$-laccase & 89.40 \\
& $\mathrm{TiO}_{2}-\mathrm{ZrO}_{2}-\mathrm{SiO}_{2}$-laccase & 93.84 \\
\hline
\end{tabular}

\section{Materials and Methods}

\subsection{Chemicals and Materials}

Titanium(IV) isopropoxide (TTIP), zirconium(IV) isopropoxide (TZIP), tetraetoxysilane (TEOS), laccase from Trametes versicolor (EC 1.10.3.2.), Alizarin Red S (ARS), Remazol Brilliant Blue R (RBBR) and Reactive Black B (RB5) (Table 6) were purchased from Sigma-Aldrich (St. Louis, MI, USA). Isopropyl alcohol (IPA), ethanol (96\%) and ammonium hydroxide solution (25\%) were obtained from Chempur Company (Piekary Ślaskie, Poland). Sodium acetate and phosphate buffer solutions at definite $\mathrm{pH}$, Coomassie Brilliant Blue G-250 (CBB G-250), 2,2-azinobis-3-ethylbenzothiazoline-6-sulfonate (ABTS), sodium azide, potassium hydrogen phthalate, potassium dichromate, mercury(I) sulphate and silver sulphate were obtained from Sigma-Aldrich (St. Louis, MO, USA). 


\subsection{Synthesis of $\mathrm{TiO}_{2}-\mathrm{ZrO}_{2}$ and $\mathrm{TiO}_{2}-\mathrm{ZrO}_{2}-\mathrm{SiO}_{2}$ Oxide Systems}

The $\mathrm{TiO}_{2}-\mathrm{ZrO}_{2}\left(\mathrm{TiO}_{2}: \mathrm{ZrO}_{2}\right.$ molar ratio 8:2) and $\mathrm{TiO}_{2}-\mathrm{ZrO}_{2}-\mathrm{SiO}_{2}\left(\mathrm{TiO}_{2}: \mathrm{ZrO}_{2}: \mathrm{SiO}_{2}\right.$ molar ratio 8:1:1) oxide systems were synthesized by the sol-gel method according to our previous study [23] with slight modifications. Briefly, TTIP was dissolved in $100 \mathrm{~mL}$ of IPA contained in a three-neck flask. The reaction system was mixed with the assumed speed of $1000 \mathrm{rpm}$ using Eurostar Digital high-speed stirrer (Ika Werke GmbH, Staufen im Breisgau, Germany) with simultaneous dosing of $10 \mathrm{~mL}$ of ammonia/deionized water mixture as catalyst at speed of $1 \mathrm{~mL} / \mathrm{min}$ using ISM833A pump (ISMATEC, Wertheim, Germany). After the catalyst was dispensed, the reaction mixture was mixed for $10 \mathrm{~min}$. After this time, the proper volume of TZIP $\left(22 \mathrm{~mL}\right.$ for synthesis of $\mathrm{TiO}_{2}-\mathrm{ZrO}_{2}$ and $11 \mathrm{~mL}$ for $\left.\mathrm{TiO}_{2}-\mathrm{ZrO}_{2}-\mathrm{SiO}_{2}\right)$ and TEOS $\left(6 \mathrm{~mL}\right.$ for synthesis of $\left.\mathrm{TiO}_{2}-\mathrm{ZrO}_{2}-\mathrm{SiO}_{2}\right)$ were added to the solution at a constant rate of $1 \mathrm{~mL} / \mathrm{min}$. After $1 \mathrm{~h}$ of reaction, the obtained systems were placed under a fume hood until gels were obtained. Then, the gelled materials were dried at $105^{\circ} \mathrm{C}$ for $6 \mathrm{~h}$ in a SEL-I3 chamber drier (Memmert, Schwabach, Germany). Finally, the oxide systems were washed five times with deionized water and two times with ethanol in order to remove unreacted components and dried for $6 \mathrm{~h}$ at $80^{\circ} \mathrm{C}$. Prior to use the samples were calcinated in a furnace Controller P320 from Nabertherm (Lilienthal, Germany) at $800{ }^{\circ} \mathrm{C}$ for $2 \mathrm{~h}$ and after that were subjected to classification.

Table 6. General characteristic of the dyes used in the study. * based on own measurements.

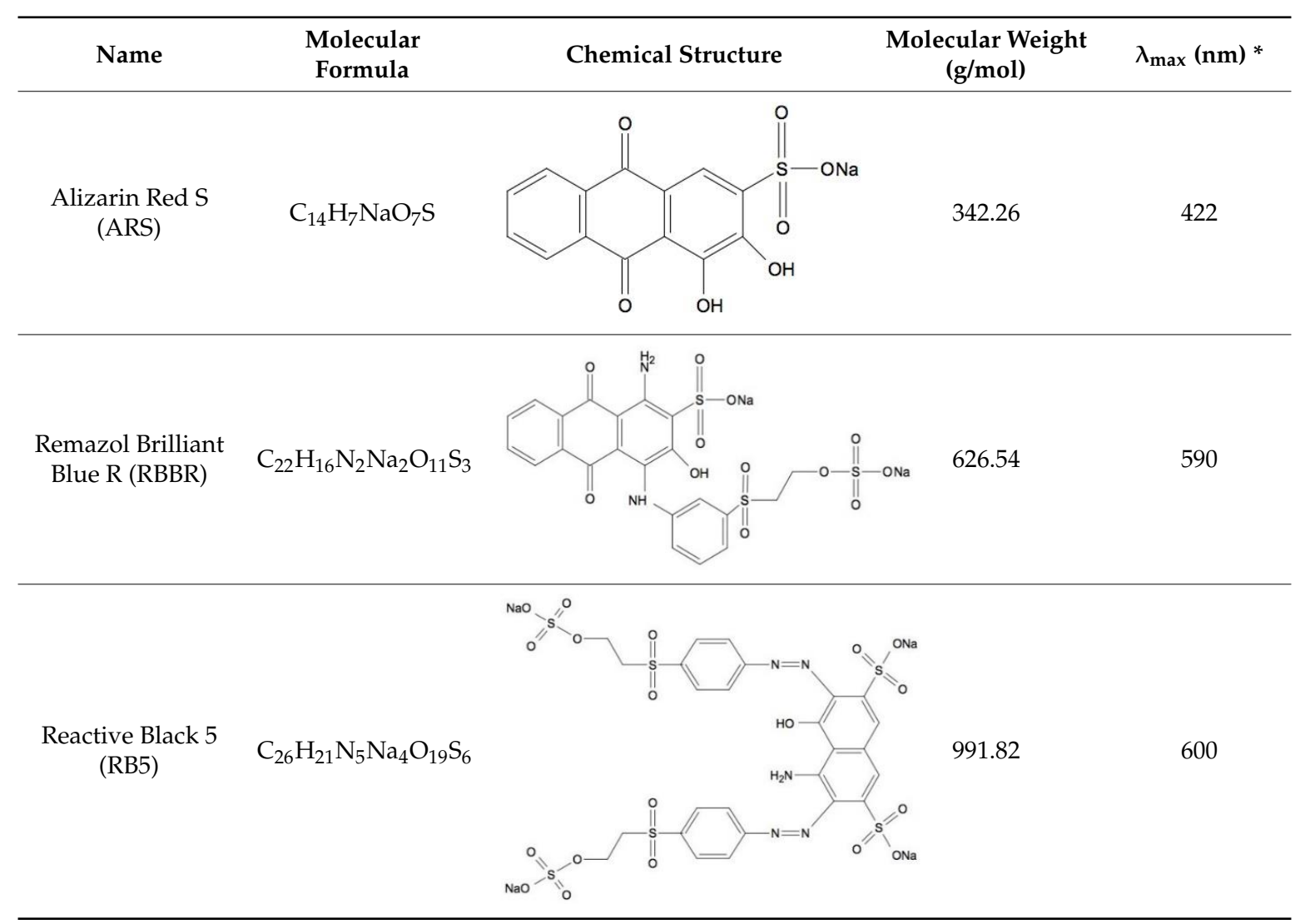

\subsection{Laccase Immobilization}

For the immobilization process, $100 \mathrm{mg}$ of the previously obtained $\mathrm{TiO}_{2}-\mathrm{ZrO}_{2}$ or $\mathrm{TiO}_{2}-\mathrm{ZrO}_{2}-\mathrm{SiO}_{2}$ materials were placed into the vials with $10 \mathrm{~mL}$ of enzyme solution at a concentration of $1 \mathrm{mg} / \mathrm{mL}$ in $\mathrm{pH} 5$ sodium acetate buffer solution. Immobilization was carried out for $2 \mathrm{~h}$ in an IKA KS 4000i control incubator (Ika Werke GmbH, Staufen im Breisgau, Germany) at room temperature. After this time, the products were centrifuged on a LLG uniCFUGE 5 (LLG Labware, Meckenheim, Ireland) at $4000 \mathrm{rpm}$ and washed several times with sodium acetate buffer at pH 5 to remove unbounded enzyme. 


\subsection{Storage Stability and Kinetic Measurements of Free and Immobilized Laccase}

The storage stability of free and immobilized biocatalyst was investigated using the following procedure. Native and immobilized laccase were stored at $4{ }^{\circ} \mathrm{C}$ in sodium acetate buffer at $\mathrm{pH} 5$. ABTS was used as the substrate for free and immobilized enzyme. Spectrophotometric tests were made over 50 days every specified period of time. During catalytic reaction absorbance was measured at $\lambda=420 \mathrm{~nm}$ using a V-750 spectrophotometer from Jasco (Tokyo, Japan). The Michaelis-Menten constant $\left(K_{m}\right)$ and the maximum rate of reaction $\left(V_{\max }\right)$ were evaluated based on the oxidation reaction of ABTS using various concentrations of the substrate solution. The Hanes-Wolf plot was used to calculate the apparent kinetic parameters $\left(K_{m}\right.$ and $\left.V_{\max }\right)$ of free and immobilized laccase.

\subsection{Dyes Degradation Experiments}

Firstly, the efficiency of sorption of dye on the support with inactivated enzyme was determined. Briefly, the $\mathrm{TiO}_{2}-\mathrm{ZrO}_{2}$ and $\mathrm{TiO}_{2}-\mathrm{ZrO}_{2}-\mathrm{SiO}_{2}$ oxide systems with immobilized enzyme were incubated at $80^{\circ} \mathrm{C}$ for $2 \mathrm{~h}$, which caused protein deactivation. Further, $50 \mathrm{mg}$ of each of the prepared materials was placed into the vials and sorption efficiency of the dyes was evaluated using $10 \mathrm{~mL}$ of selected dye solution at three concentrations: 1,5 , and $10 \mathrm{mg} / \mathrm{L}$ and at $\mathrm{pH} 5$ and $25^{\circ} \mathrm{C}$ over $24 \mathrm{~h}$. Each of the samples was placed in an IKA KS 260 Basic from Ika Werke (Staufen im Breisgau, Germany) shaker.

Bioremediation of the ARS, RBBR, and RB5 dyes was carried out in an IKA KS 260 Basic from Ika Werke (Staufen im Breisgau, Germany) shaker using $10 \mathrm{~mL}$ of dye solution and $50 \mathrm{mg}$ of the free and immobilized enzyme for $24 \mathrm{~h}$. To establish the effect of the dye concentration on degradation efficiency of ARS, RBBR, and RB5, experiments were carried out at $25^{\circ} \mathrm{C}$ and at $\mathrm{pH} 5$. Three concentrations of dyes were chosen: 1.0, 5.0, and $10.0 \mathrm{mg} / \mathrm{L}$. The influence of $\mathrm{pH}$ on the degradation efficiency of ARS, RBBR, and RB5 was examined using dye solution at a concentration of $5 \mathrm{mg} / \mathrm{L}$ at $25^{\circ} \mathrm{C}$ and $\mathrm{pH} 4$, 5 , and 6 . The effect of temperature on the removal efficiency of the tested dyes was evaluated using dye solutions at a concentration of $5 \mathrm{mg} / \mathrm{L}$ at pH 5 at temperatures of 5,25 , and $50{ }^{\circ} \mathrm{C}$. During the investigation of the dyes degradation, experiments in which the removal of dyes mixture were carried out. The dyes mixture at the final concentration of $5 \mathrm{mg} / \mathrm{L}$ was prepared by proper dilution and mixing equal volumes of the ARS, RBBR, and RB5 dye solutions. The removal of the obtained solution was performed at $\mathrm{pH} 5$ and at $25^{\circ} \mathrm{C}$.

In order to determine the reusability of the laccase immobilized onto oxide systems, five consecutive catalytic cycles were carried out. After each of the reaction cycles (time of one cycle was $24 \mathrm{~h}$ ), material with an immobilized enzyme was separated from the reaction mixture by centrifugation using an Eppendorf centrifuge $5810 \mathrm{R}$ (Germany), and washed several times with acetate buffer at $\mathrm{pH}$ 5 and used again. The reusability tests were carried out at temperature of $25^{\circ} \mathrm{C}$ using ARS, RBBR, RB5, and dye mixture solutions at a concentration of $5 \mathrm{mg} / \mathrm{L}$ prepared in a sodium acetate buffer at $\mathrm{pH} 5$. All the above-mentioned experiments were carried out in triplicate and the results are presented as a mean value.

\subsection{Analytical Techniques}

The morphology and microstructure of the $\mathrm{TiO}_{2}-\mathrm{ZrO}_{2}$ and $\mathrm{TiO}_{2}-\mathrm{ZrO}_{2}-\mathrm{SiO}_{2}$ oxide systems were observed using a EVO40 scanning electron microscope (SEM, Zeiss, Jena, Germany) and a Jeol 1200 EX II transmission electron microscope (TEM, Jeol, Peabody, MA, USA). To determine and identify the crystalline phases of the synthesized binary and ternary oxide materials, XRD was carried out. XRD analysis was performed in a D8 Advance X-ray diffractometer (Bruker, Billerica, MA, USA) operating with $\mathrm{Cu} \mathrm{K} \alpha$ radiation $(\alpha=1.5418 \AA), 30 \mathrm{~mA}$ and Ni filter. The patterns were obtained in step-scanning mode $\left(\Delta 2 \theta=0.05^{\circ}\right)$ over an angular range of $10-80^{\circ}$. An ASAP 2020 physisorption analyzer (Micromeritics Instrument Co., Norcross, CA, USA) was used to determine the porous structure parameters of mixed oxide systems based on titania, zirconia, and silica, including Brunauer-Emmett-Teller (BET) surface area, pore volume and pore size, using nitrogen as adsorbent at 
liquid-nitrogen temperature. Before measurement, the synthesized materials were degassed at $120^{\circ} \mathrm{C}$ for $4 \mathrm{~h}$. The surface area was determined by the multipoint BET method using adsorption data for relative pressure $\left(p / p_{0}\right)$ in the range of $0.05-0.30$. The desorption isotherm was used to determine the pore size distribution by the Barrett-Joyner-Halenda (BJH) method using the Halsey equation as well as the total volume of pores. FTIR spectra were obtained in the wavenumber ranging from 4000 to $400 \mathrm{~cm}^{-1}$ using Vertex 70 apparatus from Bruker (Billerica, MA, USA) by analyzing samples in the form of pellets obtained after mixing $1.5 \mathrm{mg}$ of the analyzed sample with $200 \mathrm{mg}$ of anhydrous $\mathrm{KBr}$.

Due to the use of UV-Vis spectroscopy, it was possible to evaluate the amount of immobilized enzyme onto the prepared oxide supports. It was measured by difference in the initial enzyme dosage and the concentration of enzyme after immobilization. Measurements for Commasie Brilliant Blue G250 were made at wavelength $595 \mathrm{~nm}$ using a V-750 spectrophotometer from Jasco (Tokyo, Japan), according to the Bradford method [52].

Using UV-Vis spectroscopy, changes in the concentration of the dyes during the process of their degradation were measured. The measurements were performed at wavelengths of $422 \mathrm{~nm}$ for ARS, $590 \mathrm{~nm}$ for RBBR, and $600 \mathrm{~nm}$ for RB5. The above-mentioned tests were made using a V-750 spectrophotometer from Jasco (Tokyo, Japan). The dyes degradation efficiency was determined by using the following Equation (1):

$$
D D(\%)=\frac{C_{B}-C_{A}}{C_{B}} \cdot 100 \%
$$

where $D D(\%)$ denotes the dye degradation efficiency, $C_{B}$ and $C_{A}$ denotes dye concentration before and after degradation, respectively.

COD was determined according to the Polish Standard (PN-74/C-04578/03) with the dichromate method which measures the amount of oxygen needed for oxidizing chemical compounds in the acidic environment created by potassium dichromate. Samples were diluted with demineralized water at a volume ratio of 1:50 and 1:100. Absorbance was measured in the spectrophotometer at wavelengths of $450 \mathrm{~nm}$ and $600 \mathrm{~nm}$ and the COD value was determined from the calibration curve. The COD reduction efficiency was determined by calculating, using Equation (2):

$$
\operatorname{COD} R E(\%)=\frac{C O D_{B}-C O D_{A}}{C O D_{B}} \cdot 100 \%
$$

where $C O D R E(\%)$ defines chemical oxygen demand reduction efficiency, $C O D_{B}$ and $C O D_{A}$ denotes chemical oxygen demand before and after dye degradation, respectively.

\section{Conclusions}

In this study, for the first time, binary and ternary oxide materials $\left(\mathrm{TiO}_{2}-\mathrm{ZrO}_{2}\right.$ and $\left.\mathrm{TiO}_{2}-\mathrm{ZrO}_{2}-\mathrm{SiO}_{2}\right)$ were used as supports for laccase immobilization. Textile dyes, such as Alizarin Red S, Remazol Brilliant Blue R, Reactive Black 5, and their mixtures were further degraded in the presence of the obtained biocatalytic systems by simultaneous enzymatic degradation and sorption onto obtained materials. The effective forming of oxide materials was confirmed based on SEMTEM, XRD, low-temperature $\mathrm{N}_{2}$ sorption and FTIR results. During the investigation, the effect of various process parameters on dye degradation efficiency was evaluated (dye concentration, $\mathrm{pH}$, temperature, and reusability). It has been shown that under optimal process conditions $\left(5 \mathrm{mg} / \mathrm{L}, \mathrm{pH} 5\right.$ and $\left.25^{\circ} \mathrm{C}\right) \mathrm{ARS}$, RBBR, and RB5 dyes were degraded with $100 \%, 91 \%$, and $77 \%$ efficiency, respectively. By contrast, laccase immobilized onto $\mathrm{Cu}$-alginate beads removed active, reactive, and direct dyes with efficiencies that do not exceed $80 \%$. However, in this study the removal of dyes by laccase action was observed. In another study, laccase was immobilized using $\mathrm{MnO}_{2}$ and $\mathrm{ZnO}$ oxides and used for the bimodal biodegradation/adsorption of ARS, but the removal efficiency reached less than $75 \%$, proving that the results presented by us are extremely promising from the point of view of practical application. Moreover, it should be emphasized that the obtained results indicated the ability of the bimodal 
removal of dyes from model aqueous solutions by enzymatic degradation and sorption through the obtained oxide materials. COD reduction was investigated, which indicated dye degradation and correlation with the results of the dye degradation efficiency. These data confirmed that the dyes mixture after degradation was less toxic compared with the solution before degradation. In our study, innovative ways to degrade textile dyes were presented. They can provide alternatives for the currently used, often insufficiently effective, methods of removing dyes from wastewater.

Author Contributions: K.A. planned the studies, carried out the experiments, evaluated the enzyme immobilization efficiency, and wrote the manuscript. J.Z. evaluated the immobilized enzyme's activity and stability, as well as developed results. K.S.-S. prepared the oxide materials and carried out the immobilization experiments. G.S. carried out the experiments. E.J. evaluated the chemical oxygen demand results. P.O.-P. participated in discussion and revised the manuscript. T.J. coordinated all the research tasks, planned the studies, developed the results, and participated in the manuscript preparation and discussions.

Funding: This research was funded by Poznan University of Technology research grant no. 03/32/DSPB/0806.

Conflicts of Interest: The authors declare no conflict of interest.

\section{References}

1. Mohammad, N.M.; Salehi, R. Dye removal from colored textile wastewater using chitosan in binary systems. Desalination 2011, 267, 64-72. [CrossRef]

2. Jabeen, U.; Shah, S.M.; Khan, S.U. Photo catalytic degradation of Alizarin Red S using ZnS and cadmium doped ZnS nanoparticles under unfiltered sunlight. Surf. Interfaces 2017, 6, 40-49. [CrossRef]

3. Kausar, A.; Iqbal, M.; Javed, A.; Aftab, K.; Nazli, Z.; Bhatti, H.N.; Nouren, S. Dyes adsorption using clay and modified clay: A review. J. Mol. Liq. 2018, 256, 395-407. [CrossRef]

4. Anjaneyulu, Y.; Chary, N.S.; Raj, D.S.S. Decolourization of industrial effluents-Available methods and emerging technologies-A review. Rev. Environ. Sci. Biotechnol. 2005, 4, 245-273. [CrossRef]

5. Faraco, V.; Pezzella, C.; Miele, A.; Giardina, P.; Sannia, G. Bio-remediation of colored industrial wastewaters by the white-rot fungi Phanerochaete chrysosporium and Pleurotus ostreatus and their enzymes. Biodegradation 2009, 20, 209-220. [CrossRef] [PubMed]

6. Hautphenne, C.; Pennickx, M.; Debaste, F. Product formation from phenolic compounds removal by laccases: A review. Environ. Technol. 2016, 5, 250-266. [CrossRef]

7. He, K.; Chen, G.; Zeng, G.; Chen, A.; Huang, A.; Shi, J.; Huang, T.; Peng, M.; Hu, L. Three-dimensional graphene supported catalysts for organic dyes degradation. Appl. Catal. B 2018, 228, 19-28. [CrossRef]

8. Ramírez-Montoya, L.A.; Hernández-Montoya, V.; Montes-Morán, M.A.; Jáuregui-Rincón, J.; Cervantes, F.J. Decolorization of dyes with different molecular properties using free and immobilized laccases from Trametes versicolor. J. Mol. Liq. 2015, 212, 30-37. [CrossRef]

9. Robinson, T.; McMullan, G.; Marchant, R.; Nigam, P. Remediation of dyes in textile effluent: A critical review on current treatment technologies with a proposed alternative. Bioresour. Technol. 2001, 77, $247-255$. [CrossRef]

10. Khataee, A.R.; Kasiri, M.B. Photocatalytic degradation of organic dyes in the presence of nanostructured titanium dioxide: Influence of the chemical structure of dyes. J. Mol. Catal. A Chem. 2010, 328, 8-26. [CrossRef]

11. Iqbal, M.; Nisar, J.; Adil, M.; Abbas, M.; Riaz, M.; Tahir, M.A.; Younus, M.; Shahid, M. Mutagenicity and cytotoxicity evaluation of photo-catalytically treated petroleum refinery wastewater using an array of bioassays. Chemosphere 2017, 168, 590-598. [CrossRef] [PubMed]

12. Kanwal, A.; Bhatti, H.N.; Iqbal, M.; Noreen, S. Basic dye adsorption onto clay/ $\mathrm{MnFe}_{2} \mathrm{O}_{4}$ composite: A mechanistic study. Water Environ. Res. 2017, 89, 301-311. [CrossRef] [PubMed]

13. El-Zahar, A.A.; Awwad, N.S.; El-Katori, E.E. Removal of bromophenol blue dye from industrial waste water by synthesizing polymer-clay composite. J. Mol. Liq. 2014, 199, 454-461. [CrossRef]

14. Selvam, P.P.; Preethi, S.; Basakaralingam, P.; Thinakaran, N.; Sivasamy, A.; Sivanesan, S. Removal of rhodamine B from aqueous solution by adsorption onto sodium montmorillonite. J. Hazard. Mater. 2008, 155, 39-44. [CrossRef] [PubMed]

15. Prigione, V.; Tigini, V.; Pezzella, C.; Anastasi, A.; Sannia, G.; Varese, G.C. Decolourisation and detoxification of textile effluents by fungal biosorption. Water Res. 2008, 42, 2911-2920. [CrossRef] [PubMed] 
16. Chairin, T.; Nitheranont, T.; Watanebe, A.; Asada, Y.; Khanongnuch, C.; Lumyong, S. Biodegradation of bisphenol A and decolorization of synthetic dyes by laccase from white-rot fungus, Trametes polyzona. Appl. Biochem. Biotechnol. 2013, 169, 539-545. [CrossRef] [PubMed]

17. Markiton, M.; Boncel, S.; Janas, D.; Chrobok, A. Highly active nanobiocatalyst from lipase noncovalently immobilized on multiwalled carbon nanotubes from Baeyer-Villiger synthesis of lactones. ACS Sustain. Chem. Eng. 2017, 5, 1685-1691. [CrossRef]

18. Roy, U.; Sengupta, S.; Banerjee, P.; Das, P.; Bhowal, A.; Datta, S. Assessment on the decolourization of textile dye (Reactive Yellow) using Pseudomonas sp. immobilized on fly ash: Response surface methodology optimization and toxicity evaluation. J. Environ. Manag. 2018, 223, 185-195. [CrossRef] [PubMed]

19. Wangpradit, R.; Chitprasert, P. Chitosan-coated Lentinus polychrous Lév.: Integrated biosorption and biodegradation systems for decolorization of anionic reactive dyes. Int. Biodeterior. Biodegrad. 2014, 93, 168-176. [CrossRef]

20. Rani, M.; Shanker, U.; Chaurasia, A.K. Catalytic potential of laccase immobilized on transition metal oxides nanomaterials: Degradation of Alizarin Red S dye. J. Environ. Chem. Eng. 2017, 5, 2730-2739. [CrossRef]

21. Xu, H.M.; Sun, X.F.; Wang, S.Y.; Song, C.; Wang, S.G. Development of laccase/graphene oxide membrane for enhanced synthetic dyes separation and degradation. Sep. Purif. Technol. 2018, 204, 255-260. [CrossRef]

22. Singh, N.; Basu, S.; Vankelecom, I.F.J.; Balakrishnan, M. Covalently immobilized laccase for decolourization of glucose-glycine maillard products as colourant of distillery wastewater. Appl. Biochem. Biotechnol. 2015, 177, 76-89. [CrossRef] [PubMed]

23. Zdarta, J.; Meyer, A.S.; Jesionowski, T.; Pinelo, M. Developments in support materials for immobilization of oxidoreductases: A comprehensive review. Adv. Colloid Interface Sci. 2018, 258, 1-20. [CrossRef] [PubMed]

24. Sun, H.; Jin, X.; Long, N.; Zhang, R. Improved biodegradation of synthetic azo dye by horseradish peroxidase cross-linked on nano-composite support. Int. J. Biol. Macromol. 2017, 95, 1049-1055. [CrossRef] [PubMed]

25. Wang, F.; Hu, Y.; Guo, C.; Huang, W.; Liu, C.Z. Enhanced phenol degradation in coking wastewater by immobilized laccase on magnetic mesoporous silica nanoparticles in a magnetically stabilized fluidized bed. Bioresour. Technol. 2012, 110, 120-124. [CrossRef] [PubMed]

26. Siwińska-Stefańska, K.; Kurc, B. A composite $\mathrm{TiO}_{2}-\mathrm{ZrO}_{2}-\mathrm{SiO}_{2}$ oxide system as a high-perfomance anode material for lithium-ion batteries. J. Electrochem. Soc. 2017, 164, A728-A734. [CrossRef]

27. Adamczyk, A. The influence of $\mathrm{ZrO}_{2}$ precursor type on the structure of $\mathrm{ZrO}_{2}-\mathrm{TiO}_{2}-\mathrm{SiO}_{2}$ gels and selected thin films. J. Mol. Struct. 2018, 1171, 706-716. [CrossRef]

28. Ilk, S.; Demircan, D.; Saglam, S.; Saglam, N.; Rzayev, Z.M.O. Immobilization of laccase onto a porous nanocomposite: Application for textile dye degradation. Turk. J. Chem. 2016, 40, 262-276. [CrossRef]

29. Zdarta, J.; Antecka, K.; Jędrzak, A.; Synoradzki, K.; Łuczak, M.; Jesionowski, T. Biopolymers conjugated with magnetite as support materials for trypsin immobilization and protein digestion. Colloids Surf. B Biointerfaces 2018, 169, 118-125. [CrossRef] [PubMed]

30. Arica, M.Y.; Senel, S.; Alaeddinoglu, N.G.; Patir, S.; Denizli, A. Invertase immobilized on spacer-arm attached poly(hydroxyethyl metacrylate) membrane: Preparation and properties. J. Appl. Polym. Sci. 2000, 75, 1685-1692. [CrossRef]

31. Klapiszewski, Ł.; Zdarta, J.; Jesionowski, T. Titania/lignin hybrid materials as a novel support for $\alpha$-amylase immobilization: A comprehensive study. Colloids Surf. B Biointerfaces 2018, 162, 90-97. [CrossRef] [PubMed]

32. Xu, R.; Chi, C.; Li, F.; Zhang, B. Laccase-polyacrylonitrile nanofibrous membrane: Highly immobilized, stable, reusable, and efficacious for 2,4,6-trichlorophenol removal. ACS Appl. Mater. Interfaces 2013, 5, 12554-12560. [CrossRef] [PubMed]

33. Zdarta, J.; Antecka, K.; Frankowski, R.; Zgoła-Grześkowiak, A.; Ehrlich, H.; Jesionowski, T. The effect of operational parameters on the biodegradation of bisphenols by Trametes versicolor laccase immobilized on Hippospongia communis spongin scaffolds. Sci. Total Environ. 2018, 615, 784-795. [CrossRef] [PubMed]

34. Vignesh Kumar, T.H.; Sivasankar, V.; Fayoud, N.; Oualid, H.A.; Sundramoorthy, A.K. Synthesis and characterization of coral-like hierarchical $\mathrm{MgO}$ incorporated fly ash composite for the effective adsorption of azo dye from aqueous solution. Appl. Surf. Sci. 2018, 449, 719-728. [CrossRef]

35. Jesionowski, T.; Przybylska, A.; Kurc, B.; Ciesielczyk, F. Hybrid pigments preparation via adsorption of C.I. Mordant Red 3 on both unmodified and aminosilane-functionalised silica supports. Dyes Pigments 2011, 89, 127-136. [CrossRef] 
36. Miyamoto, M.; Hamajiama, A.; Oumi, Y.; Uemiya, S. Effect of basicity of metal doped $\mathrm{ZrO}_{2}$ supports on hydrogen production reactions. Int. J. Hydrogen Energy 2018, 43, 730-738. [CrossRef]

37. Kamaz, M.; Rocha, P.; Sengupta, A.; Qian, X.; Wickramasinghe, R.S. Efficient removal of chemically toxic dyes using microorganism from activated sludge: Understanding sorption mechanism, kinetics, and associated thermodynamics. Sep. Sci. Technol. 2018, 53, 1760-1776. [CrossRef]

38. Jesionowski, T. Synthesis of organic-inorganic hybrids via adsorption of dye on an aminosilane-functionalised silica surface. Dyes Pigments 2002, 55, 133-141. [CrossRef]

39. Li, W.X.; Sun, H.Y.; Zhang, R.F. Immobilization of laccase on a novel $\mathrm{ZnO} / \mathrm{SiO}_{2}$ nano-composited support for dye decolorization. In Proceedings of the 2015 Global Conference on Polymer and Composite Materials, Materials Science and Engineering, Beijing, China, 16-18 May 2015; Volume 87. [CrossRef]

40. Chao, C.; Guan, H.; Zhang, J.; Liu, Y.; Zhao, Y.; Zhang, B. Immobilization of laccase onto porous vinyl alcohol/halloysite hybrid beads for dye removal. Water Sci. Technol. 2018, 77, 809-818. [CrossRef] [PubMed]

41. Rangelov, S.; Nicell, J.A. A model of the transient kinetics of laccase-catalyzed oxidation of phenol at micromolar concentrations. Biochem. Eng. J. 2015, 99, 1-15. [CrossRef]

42. Kim, Y.J.; Nicell, J.A. Impact of reaction conditions on the laccase-catalyzed conversion of bisphenol A. Bioresour. Technol. 2006, 97, 1431-1442. [CrossRef] [PubMed]

43. Reda, F.M.; Hassan, N.S.; El-Moghazy, A.N. Decolorization of synthetic dyes by free and immobilized laccases from newly isolated strain Brevibacterium halotolerans N11 (KY883983). Biocatal. Agric. Biotechnol. 2018, 15, 138-145. [CrossRef]

44. Zdarta, J.; Jędrzak, A.; Klapiszewski, Ł.; Jesionowski, T. Immobilization of cellulase on a functional inorganic-organic hybrid support: Stability and kinetic study. Catalysts 2017, 7, 374. [CrossRef]

45. Ramírez-Montoya, L.A.; Hernández-Montoya, V.; Montes-Morán, M.A.; Cervantes, F.J. Correlation between mesopore volume of carbon supports and the immobilization of laccase from Trametes versicolor for the decolorization of Acid Orange 7. J. Environ. Manag. 2015, 162, 206-214. [CrossRef] [PubMed]

46. Rahmani, K.; Faramarzi, M.A.; Mahvi, A.H.; Gholami, M.; Esrafili, A.; Forootanfar, H.; Farzadkia, M. Elimination and detoxification of sulfathiaziole and sulfamethoxazole assisted by laccase immobilized on porous silica beads. Int. Biodeterior. Biodegrad. 2015, 97, 107-114. [CrossRef]

47. Sadighi, A.; Faramarzi, M.A. Congo Red decolorization by immobilized laccase through chitosan nanoparticles on the glass beads. J. Taiwan Inst. Chem. Eng. 2013, 44, 156-162. [CrossRef]

48. Fernández-Fernández, M.; Sanromán, M.A.; Moldes, D. Recent developments and applications of immobilized laccase. Biotechnol. Adv. 2013, 31, 1808-1825. [CrossRef] [PubMed]

49. Ma, H.F.; Meng, G.; Cui, B.K.; Si, J.; Dai, Y.C. Chitosan crosslinked with genipin as supporting matrix for biodegradation of synthetic dyes: Laccase immobilization and characterization. Chem. Eng. Res. Des. 2018, 132, 664-676. [CrossRef]

50. Alinsafi, A.; da Motta, M.; Le Bonte, S.; Pons, M.N.; Benhammou, A. Effect of variability on the treatment of textile dyeing wastewater by activated sludge. Dyes Pigments 2006, 69, 31-39. [CrossRef]

51. Paz, A.; Carballo, J.; Perez, M.J.; Domínguez, J.M. Biological treatment of model dyes and textile wastewaters. Chemosphere 2017, 181, 168-177. [CrossRef] [PubMed]

52. Bradford, M.M. A rapid and sensitive method for the quantitation of microgram quantities of protein utilizing the principle of protein-dye binding. Anal. Biochem. 1976, 72, 248-254. [CrossRef]

(C) 2018 by the authors. Licensee MDPI, Basel, Switzerland. This article is an open access article distributed under the terms and conditions of the Creative Commons Attribution (CC BY) license (http://creativecommons.org/licenses/by/4.0/). 